\title{
THE IMPLICATIONS OF THE ELECTRONIC WORD-OF-MOUTH COMMUNICATION IN CHOOSING A WELLNESS OFFER
}

\author{
Milan Kocic* and Katarina Radakovic \\ Faculty of Economics, University of Kragujevac, Kragujevac, The Republic of Serbia
}

In the conditions of the dynamic development of information and communications technology, the traditional way of establishing communication among consumers has significantly changed. As one of several extremely important marketing instruments, word-of-mouth communication has been assuming a new dimension via digital forms of communicating. Having in mind the significance of social media for the formation of consumer attitudes and intentions concerning the purchasing process, the paper is aimed at obtaining relevant findings on the effect of electronic word-of-mouth communication on consumer behavior. More precisely, by using a correlation and multiple regression analysis, whether the quantity, quality and timeliness of information, and the source credibility of electronic word-of-mouth communication affect consumer trust in the area of a wellness offer was examined. A simple regression analysis was applied in order to determine whether consumer trust contributed to purchase intention. The results of the conducted empirical research show that there is a statistically significant impact of electronic word-of-mouth communication on consumer trust and that consumer trust positively affects purchase intention when choosing a wellness package in the Republic of Serbia is concerned.

Keywords: electronic word-of-mouth communication, consumer attitudes, purchasing behavior, social media, wellness offer

JEL Classification: M31, D830, I0

\section{INTRODUCTION}

The traditional forms of marketing communications are losing their effectiveness in the framework of the consumer behavior characterized by great dynamism (Trusov, Bucklin \& Pauwels, 2009), which is precisely

* Correspondence to: M. Kocić, Faculty of Economics, University of Kragujevac, Liceja Kneževine Srbije 3, 34000 Kragujevac, The Republic of Serbia; e-mail: mkocic@kg.ac.rs why word-of-mouth (WOM) communication is listed as a powerful marketing instrument. The word-of-mouth communication process involves communication between the sender and the receiver, which refers to a product, brand or service (Senić \& Senić, 2008). As one of the oldest forms of obtaining information in the process of searching for, choosing and using products or services, word-of-mouth communication enables the transfer of shopping experiences to other people (Stanković and Đukić, 
2014). Lately, as a consequence of companies' endeavors to position themselves in a competitive market, there has been almost no business entity not using some forms of digital marketing in their business strategies, which is the reason why the field of communications has also been spreading into the online environment. That is why classic WOM communication is increasingly being replaced with electronic wordof-mouth communication. An increasing number of consumers make their decisions concerning their purchase based on the information created and posted by other consumers in an online environment (Hu, Bose, Koh \& Liu, 2012). Namely, with the intensification of the use of Internet technologies, the way in which people read, write, collect information and share experiences is changing (Casaló, Flavián \& Guinalíu, 2011). According to the latest research, $72.9 \%$ of households in the Republic of Serbia own an Internet connection port, which is an increase of $4.9 \%$ compared to 2017, and an increase of $8.2 \%$ compared to 2016 . Around $73 \%$ of them have used the Internet in the past three months (Statistical Office of the Republic of Serbia). In virtual communities, people exchange experiences, form friendships and share information (Wu, Chen \& Chung, 2010). It is exactly for that reason, especially in the tourism sector, that the role of electronic word-of-mouth communication has been ever-increasing. The intensive application of electronic word-of-mouth communication primarily reflects on the service sector, thus affecting consumer purchasing behavior when opting for tourist offers and accommodation capacities (Sa'ait, Kanyan \& Fitri Nazrin, 2016). The potential users of certain tourist destinations carry out a cost/benefit analysis of alternative destinations, whereby they use electronic word-of-mouth communication as one of the external sources of information (Abubakar, 2016). This paper intends to test the effect of electronic word-of-mouth communication in the context of social media, disregarding their specific points. Therefore, in the context of conducting the research study, the term 'social media' implies numerous kinds of content on the Internet, such as forums, blogs, websites for exchanging experiences and all other virtual forms contributing to emphasizing communication among consumers.
The subject matter of the paper refers to examining the impact of electronic word-of-mouth communication through the characteristics of a message, as well as its source, on the creation of trust and an increase in the intention of purchasing behavior when speaking about a wellness offer. Having in mind the specificity of wellness packages as one of the modern forms of tourism, the analysis of the relevant literature has shown that there are an insufficient number of the research studies targeting the matters of electronic word-of-mouth communication in this field. Taking into consideration the indicators that show a growing trend of the wellness offer, marketing potentials are extremely important in the analysis of this problem area. Since ever-higher budgets are being allocated for wellness activities, this field certainly contributes to the development of the tourism offer in the future. Relying on the already identified connection between electronic word-of-mouth communication and consumer purchasing behavior in the tourism offer (Albarq, 2014), the research study was conducted on the territory of the Republic of Serbia. Some of the specific aims of the research study include the following:

- to examine whether the quantity, quality and timeliness of information in electronic word-ofmouth communication affect consumer trust in wellness packages;

- to reach relevant findings on whether the source characteristics in electronic word-ofmouth communication, more precisely implying credibility, affect consumer trust in wellness packages;

- to ascertain whether there is a statistically significant effect between consumer trust and purchase intention when choosing a wellness offer.

The theoretical and methodological set of instruments in the paper involves the application of the methods of analysis and synthesis, as well as a descriptive study and interpretation of the results. Also, the survey method was applied in order to carry out empirical research. In order to test the defined hypotheses, reliability analysis, correlation analysis, and multiple and simple regression analyses are used. 
The paper is so structured that the theoretical terms concerning the basic trends in the field of wellness tourism, as well as the variables predominantly defining electronic word-of-mouth communication, are elaborated on after the introductory considerations by conducting a content analysis $t$. In accordance with the existing theoretical overview and the results of the previous research, several hypotheses are formulated in this paper. The following segment shows the methodological framework, defines the conceptual research model and elaborates on the results of the empirical research. In the last research segment, the conclusions, as well as the limitations and future directions specific to the research problem, are presented.

The originality and value of the research study arise from the fact that there are an insufficient number of the papers in the Republic of Serbia related to the examination of the individual variables of electronic word-of-mouth communication in the given field. Although the role of this form of communication was examined in the previous research frameworks in general, the wellness industry is undoubtedly a topic insufficiently researched from this aspect.

\section{LITERATURE REVIEW}

\section{The Characteristics of Wellness Tourism}

As a relatively new form of health tourism (Težak Damijanić \& Šergo, 2014), the wellness industry has increasingly been catching the attention of marketing experts. Wellness packages refer to the proactive side of the users, including their attitudes towards preventing diseases, improving health and maintaining the quality of life. According to $\mathrm{H}$. Mueller and E. Kaufmann (2001), wellness is defined as "a state of health featuring the harmony of body, mind and spirit, with self-responsibility, physical fitness/beauty care, healthy nutrition/diet, relaxation (need for distressing)/meditation, mental activity/ education and environmental sensitivity/social contacts as fundamental elements".
Considering the intensification of investment in wellness packages in the Republic of Serbia, starting from the first wellness center in Vrnjačka Banja in 2005, it is of crucial importance that the manner in which modern tendencies in marketing, such as electronic word-of-mouth communication, affect consumers' choices should be considered. The communication channels using the Internet are the most important distribution channels in the field of wellness tourism, which is the reason why the potential for commercialization by using online platforms is the field with plenty of room for research. Bearing in mind the fact that the wellness offer is primarily aimed at improving the quality of life and achieving a harmony, rather than a classic treatment (Koncul, 2012), this form of tourism may be suitable for electronic word-of-mouth communication amongst potential or current users. The potential users of tourist packages rely on the information obtained from the online environment, bearing in mind the fact that a tourist product is not available up to the moment of its actual usage, which is why risk and uncertainty are greater (Abubakar, 2016).

\section{The Conceptual Foundations of Electronic Word-of-mouth Communication}

Today, in the era of the development of information and communication technology, classic word-ofmouth communication (WOM) is analyzed through the digital environment. Having in mind an increasing number of Internet users, business entities in numerous fields have recognized the significant possibilities that come alongside digitalization. The use of digital content is no longer a matter of choice, but rather a matter of necessity, which is often the key to the existence in an increasingly competitive market. Electronic word-of-mouth communication is defined as "any positive or negative statement made by a potential, actual or former customer about a product or company, which enables the exchange of attitudes among individuals or institutions using Internet platforms" (Hennig-Thurau \& Walsh, 2004). Electronic word-of-mouth communication can be realized in a completely digital environment, no matter whether social networks, websites for sharing 
interactive content, microblogs, forums and all the other forms that contribute to the exchange of experiences, opinions and attitudes of the users of different products and services are in question. The impact of electronic word-of-mouth communication on consumer purchasing behavior is the subject of numerous research studies (Fan \& Miao, 2012; Prasad, Gupta \& Totala, 2016). This form of exchanging consumers' experiences and knowledge significantly defines their purchasing behavior (Marinković, Senić, Obradović \& Šapić, 2012). That is the reason why it is extremely important for the creators of marketing strategies to properly consider the significance and potential of this form of communication. The easier availability of online comments, as well as anonymity in the exchange of attitudes and experiences, are just some factors emphasizing the significance of electronic word-of-mouth communication compared to traditional communication in an offline environment (Bellman, Johnson, Loshe \& Mandel, 2006). The fact that, in comparison with traditional communication, electronic word-of-mouth communication communication is not limited to a small number of users, but it has a great reach and can involve a significant number of online users, is stated as one of the main characteristics which the advantage of electronic word-of-mouth communication is based on (HennigThurau, Gwinner, Walsh \& Gremler, 2004). According to some research studies (Xiaorong, Bin, Qinghong, Liuli \& Yu, 2011), electronic word-of-mouth communication greatly decreases the consumer distrust associated with online shopping which may arise from the perceived risk or insufficient and asymmetrical information. This paper lists some of the most commonly analyzed criteria as the key factors that characterize the information posted by using electronic word-of-mouth communication. These are the quality of the message, the quantity and timeliness of information.

\section{The Quantity of Information in Electronic Word-of-Mouth Communication}

Bearing in mind the intangible nature of products or services in the virtual environment, when consumers need to make a choice, it is very important for them to have as much information as possible at their disposal, i.e. the comments which would decrease their risk when making a decision. One of the variables examined in the paper is the quantity of information. Starting from the prior research, whether a greater number of available information in electronic wordof-mouth communication strengthens consumer trust and affects the decision concerning the choice of a certain wellness offer or not will be examined. According to the research targeting this field, consumer trust is intensified if a larger number of users leave a comment in electronic word-of-mouth communication (Xiaorong, Bin, Qinghong, Liuli \&Yu, 2011). That is why the following hypothesis will be tested for the purpose of examining this variable when choosing a wellness offer:

H1: The quantity of information in electronic wordof-mouth communication has a positive and statistically significant impact on consumer trust when choosing a wellness offer.

\section{The Quality of Information in Electronic Word-of-Mouth Communication}

The variable that is most frequently an inseparable part of research alongside the quantity of information is the quality of electronic word-of-mouth communication. Even in papers from an earlier period, the quality of information was defined as a significant indicator of the success of information systems (Fan, Miao, Fang \& Lin, 2013). Most authors have a unified position that the quality of information is one of the key determinants directing the consumer's decision when choosing a certain product or service. So, for instance, Y. W. Fan et al (2011) point out that the quality of electronic word-of-mouth communication is exactly the factor affecting consumer trust most and that the online comments containing enough arguments and facts are crucial to consumer trust. Based on the given theoretical overview, the second hypothesis is defined:

H2: The quality of information in electronic wordof-mouth communication has a positive and statistically significant impact on consumer trust when choosing a wellness offer. 


\section{The Timeliness of Information in Electronic Word-of-mouth Communication}

Taking into consideration the dynamic nature of the virtual environment, consumers are exposed to the updated content which is of interest to them on a daily basis. The timeliness dimension, i.e. the period from the moment when a message was created online to the moment it is used by another potential user, is mentioned as one of the factors defining electronic word-of-mouth communication. Timeliness is defined as the period that passes from the moment when a user leaves a comment in electronic word-of-mouth communication to the moment when a potential user consults the same comment when making a choice. The research study conducted in 2017 confirms that the more recent the comments, the higher the degree of the trust of the potential users of tourist services (Coursaris, Van Osch \& Albini, 2017). With respect to the said, the third hypothesis is defined:

H3: The timeliness of information in electronic word-of-mouth communication has a positive and statistically significant impact on consumer trust when choosing a wellness offer.

\section{Source Credibility in Electronic Word-of- Mouth Communication}

In addition to the characteristics of the message, which have been explained by using the three given dimensions, the source credibility in electronic word-of-mouth communication can be one of the determinants of consumer trust (Lopez \& Sicilia, 2014). This is one of the variables that has a positive effect on consumer purchasing behavior (Shuqair, Cragg, Zaidan \& Mitchell, 2016), which has also been confirmed through the research studies conducted on the territory of Serbia, Croatia and Bosnia and Herzegovina (Kursan, Milaković, Mihić \& Ivasečko, 2017). For that reason, this paper will determine the effect the sources of information have on trust and purchasing behavior, together with the characteristics of information in electronic word-ofmouth communication in the process of choosing a wellness offer. Some factors that have a dominant impact on consumer trust refer to the competences, truthfulness and good intentions of the source of the message (Flavián, Guinalíu \& Gurrea, 2006; Casaló, Flavián \& Guinalíu, 2011). The aim is to investigate whether the consumer trust created through these variables affects purchasing behavior when choosing a wellness offer. In terms of truthfulness, it refers to the belief that other members, i.e. participants, in electronic word-of-mouth communication will keep their word, fulfill their promise, i.e. that they will be truthful in communicating in an online environment with other participants (Casaló, Flavián \& Guinalíu, 2011). Good intentions refer to the altruistic motive and involvement in electronic word-of-mouth communication with the intention to help and support, i.e. to demonstrate care for other participants (Wu, Chen \& Chung, 2010). In an online environment, the members should answer other users' questions and proactively consider what their wishes and needs are (Wu, Chen \& Chung, 2010). When speaking about competence, i.e. expertise, it is also one of the variables that affect consumer trust. It is defined as a perceived level of skills and knowledge in the process of electronic word-of-mouth communication shown by other participants (Coulter, Coulter, 2002). Even though there are numerous research questions aimed at investigating the given field, there is little research investigating these relations in the territory of the Republic of Serbia. There is a significant effect between the consumer trust defined through these three dimensions and purchasing behavior in the field of the tourism offer, especially when selecting destinations is concerned (Curras-Perez, Ruiz, Sanchez-Garcia \& Sanz, 2017). That is why companies in the tourism sector should strive to increase consumer trust in the online environment.

H4: The source credibility in electronic word-ofmouth communication has a positive and statistically significant impact on consumer trust when choosing a wellness offer.

\section{Trust and Purchase Intention}

In an online environment, a product cannot be touched, felt, and one cannot look the clerk in the eye (Gommans, Krishnan \& Scheffold, 2001). Consumer trust is another key variable that affects consumer 
purchasing behavior (Alfina, Ero, Hidayanto \& Shihab, 2014). When electronic word-of-mouth communication is in question, trust is a relevant factor determining a decision when making a choice, because electronic written words are formal and considered as more truthful (Marić, Kovač Žnideršić, Paskaš, Jevtić and Kanjuga, 2017). Namely, it has been proven that exactly those websites which consumers trust most have the biggest success in the online environment (Prasad, Gupta \& Totala, 2017). According to the research, there is a higher degree of trust in the online comments written by the other users of the offer compared to those written by experts (Belarmino \& Koh, 2018). Because of the intangible nature of services in the tourism sector, most users base their choice precisely on the pieces of information posted in electronic word-of-mouth communication. M. Kimery and M. Mc Cord (2002) point out that trust in an online environment helps to decrease the risk which the consumer is faced with. By means of using an in-depth interview, S. Prasad, I. Gupta and N. Totala (2017) explain that the effect of electronic word-of-mouth communication on purchase intention is realized exactly through consumer trust. In marketing research, intention in behavior refers to a high probability of expressing a certain type of behavior (Sapic, 2017). Purchase intention in an online environment, which is characterized by a higher degree of uncertainty and risk, is often directly influenced by the level of consumers' confidence. In accordance with the results of the previous research, trust is directly related to purchasing behavior (Xiaorong, Bin, Qinghong, Liuli \& Yu, 2011).

H5: Consumer trust in electronic word-of-mouth communication has a positive and statistically significant impact on purchase intention when choosing a wellness offer.

\section{RESEARCH METHODOLOGY}

Starting from a detailed elaboration of the theoretical concepts, empirical research was conducted in this paper. The research was aimed at examining the connection between electronic word-of-mouth communication and consumer trust, and analyzing trust as a determinant of purchasing behavior when choosing a wellness offer. In order to collect data, a questionnaire was distributed to the respondents in the territory of Kragujevac in a classic form, and the respondents were supposed to fill in the question sheets. The survey was conducted by using a simple random sample through direct contact with respondents. A total of 150 questionnaires were distributed, out of which 124 questionnaires are valid with a high response rate $(82.7 \%)$. Empirical research was carried out by applying the survey method in the period from August to October, 2018. In order to obtain valid results, the data were filtered out by taking into consideration only those respondents who had pointed out that they had previously used some wellness packages in the Republic of Serbia. The questionnaire was structured in such a way that it contained, first of all, general information, such as: sex, age, education and the working status, then the conclusions connected with all the variables examined. The respondents expressed the degree of their respective agreement upon the findings stated in the questionnaire by means of a five-point Likert scale (number 1 - I do not agree at all, number 5 - I absolutely agree), which is one of the methods most commonly used to make valid conclusions in this type of research.

The variables used in the questionnaire were measured by the constatations that were taken and adapted according to the research needs. The quantitative and qualitative information related to electronic word-of-mouth communication was adapted and adjusted according to (Lin, $\mathrm{Wu}$, Chen, 2013). The timeliness of the information in electronic word-of-mouth communication was evaluated by means of the statements formulated based on the author (Sa'ait, Kanyan \& Fitri Nazrin, 2016), whereas the credibility of the source was adjusted according to the findings (Kursan Milaković, Mihić and Ivasečko, 2017). Consumer trust was evaluated through the constatations tailored to the research study (Zainal, Harun \& Lily, 2017), whereas the intention to purchase wellness packages was evaluated through the findings adapted to (Abdelaziz, Aziz, Khalifa \& Ma'youf, 2015). In order to examine the relationship between the observed variables, the hypotheses 
were tested by using descriptive statistics, reliability analysis, correlation analysis, and free and multiple regression. The impact of the four analyzed variables on consumer trust was examined through multiple regression, whereas the impact of trust on purchasing behavior when making a choice of wellness content was tested through simple regression analysis. The data analysis was performed in the statistical package for social sciences (The Statistical Package for the Social Sciences-SPSS, version 21) and Eviews 7. Taking into account the defined variables, the research model shown in Figure 1 was defined for the purpose of the research in accordance with the theoretical examination and the hypotheses set.

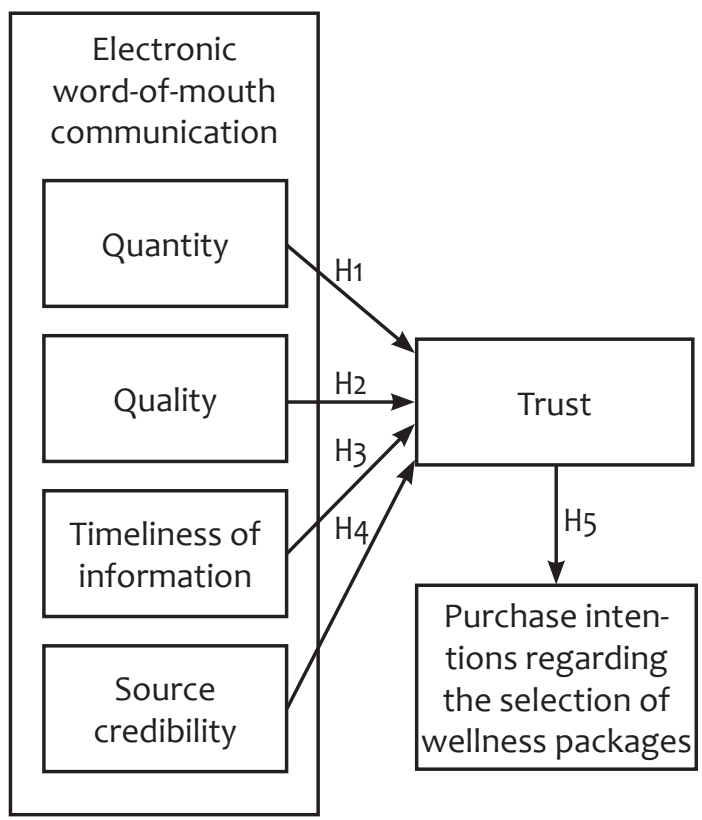

Figure 1. The conceptual model of the research Source: Authors

\section{RESEARCH RESULTS}

The survey included 124 respondents of different demographic profiles presented in Table 1.

Based on the demographic structure of the respondents, it can be noticed that the percentage of the female respondents is higher (57.3\%). When the age factor of the interviewees is concerned, the majority of the respondents belong to the age category ranging from 25 to 31 , whereas the fewest respondents are over the age $60(7.3 \%)$. Also, the table shows that the highest percentage of the respondents account for those with higher education $(40.3 \%)$, whereas among the employed, the largest number of them are clerks $(24.2 \%)$, and the retired are the least present in our sample (4.8\%).

In the initial steps of our research, the results of the analysis of the descriptive statistics were presented in order to examine the benefits and homogeneity, i.e. the heterogeneity of the respondents' attitudes. By observing Table 2, it can be noticed that the value of

Table 1 The demographic structure of the respondents

\begin{tabular}{l|cc}
\hline Demographic profile & Frequency & $\%$ \\
\hline Gender & 53 & 42.7 \\
Male & 71 & 57.3 \\
Female & & \\
Age & 16 & 12.9 \\
$18-24$ & 27 & 21.8 \\
$25-31$ & 20 & 16.1 \\
$32-38$ & 19 & 15.3 \\
$39-45$ & 16 & 12.9 \\
$46-52$ & 17 & 13.7 \\
$53-59$ & 9 & 7.3 \\
60 and older & & \\
Education & 2 & 1.6 \\
Elementary education & 38 & 30.6 \\
Secondary education & 34 & 27.4 \\
Higher education & 50 & 40.3 \\
College education & & \\
Working status & 14 & 11.3 \\
Student & 26 & 21.0 \\
Manager, Entrepreneur & 22 & 17.7 \\
Professor, Medical doctor, & & \\
Engineer & 30 & 24.2 \\
Clerk & 26 & 21.0 \\
Worker & 6 & 4.8 \\
Retired person & &
\end{tabular}

Source: Authors 
Table 2 The results of the descriptive statistics for the given constatations

\begin{tabular}{|c|c|c|}
\hline Constatation & $\begin{array}{l}\text { Arithmetic } \\
\text { mean }\end{array}$ & $\begin{array}{l}\text { Standard } \\
\text { deviation }\end{array}$ \\
\hline \multicolumn{3}{|l|}{ Quantity } \\
\hline The more online comments there are. the more popular a wellness offer is. & 4.12 & 0.694 \\
\hline The more online comments there are. the better sales can be achieved by the wellness offer. & 4.08 & 0.739 \\
\hline $\begin{array}{l}\text { A large number of the comments which are highly rated and recommendations in the online } \\
\text { environment show that the wellness offer has a good reputation. }\end{array}$ & 4.19 & 0.679 \\
\hline \multicolumn{3}{|l|}{ Quality } \\
\hline It is important to me that online comments on wellness offers are clear. & 4.36 & 0.629 \\
\hline It is important to me that online comments on wellness offers are understandable. & 4.42 & 0.613 \\
\hline It is important to me that online comments on wellness offers are useful. & 4.44 & 0.629 \\
\hline $\begin{array}{l}\text { Generally speaking. it is important to me that the quality of the comments regarding the wellness } \\
\text { offer is high. }\end{array}$ & 4.48 & 0.631 \\
\hline \multicolumn{3}{|l|}{ Timeliness of information } \\
\hline It is important to me that the online comments on wellness offers are as current as possible. & 4.21 & 0.641 \\
\hline $\begin{array}{l}\text { It is important to me that online comments on wellness offers are new. i.e. in accordance with the } \\
\text { current trends. }\end{array}$ & 4.25 & 0.670 \\
\hline It is important to me that online users' comments on a wellness offer are up-to-date and valid. & 4.27 & 0.639 \\
\hline \multicolumn{3}{|l|}{ Source credibility } \\
\hline $\begin{array}{l}\text { When choosing a wellness offer. I can trust the information I obtain from other users in the online } \\
\text { environment. }\end{array}$ & 4.06 & 0.695 \\
\hline I believe that other users in online communication give honest comments on wellness packages. & 4.00 & 0.721 \\
\hline I believe that other users in online communication give useful comments on wellness packages. & 4.02 & 0.743 \\
\hline \multicolumn{3}{|l|}{ Trust } \\
\hline Participants in online communication are competent when discussing wellness offers. & 4.12 & 0.645 \\
\hline Most of the other users of wellness packages in the online environment do not give false comments. & 4.02 & 0.715 \\
\hline I believe that I can trust the online comments given by other wellness users. & 3.96 & 0.726 \\
\hline $\begin{array}{l}\text { The users of wellness packages take into account the needs of other members when writing online } \\
\text { comments. }\end{array}$ & 4.08 & 0.705 \\
\hline \multicolumn{3}{|l|}{ Purchase intention } \\
\hline Previous online comments on the wellness offer affect my willingness to book it. & 4.27 & 0.629 \\
\hline When I think that a wellness offer is as good as is described in online comments. I am ready to book it. & 4.33 & 0.634 \\
\hline My choice of a wellness offer is based on the online comments I read. & 4.37 & 0.618 \\
\hline The information I obtain in online communication affects my choice of wellness offers. & 4.35 & 0.612 \\
\hline
\end{tabular}


the arithmetic mean is high for all the constatations, with the highest value referring to the fact that it is important for the respondents to have high quality online comments (the arithmetic mean being 4.48), whereas the lowest value of the arithmetic mean refers to trust in the online comments provided by the other users of wellness packages (3.96). Regarding the homogeneity of the respondents' attitudes, the highest degree of agreement, i.e. the lowest value of the standard deviation (0.612), was observed in the statement regarding the intention to purchase the wellness content based on the information obtained online, whereas the highest heterogeneity of the respondents' attitudes, i.e. the largest standard deviation, was observed in the constatation realting to the statement that the other users in online communication give useful comments when with respect to choosing a wellness offer (the standard deviation being 0.743 ).

In order to test the reliability and internal consistency of the constatations defined in the paper, the value of Cronbach's alpha coefficient was calculated for all the observed variables. Since the acceptable value of this coefficient is higher than 0.7 (Nunnally, 1978), by observing Table 3, a conclusion can be drawn that all of these variables fulfill the given criterion.

After the examination of internal consistency, a correlation matrix was presented so as to examine the strength and direction of the connection among the observed variables. By considering the value of the Pearson coefficient, it can be concluded that there is a correlation between all the variables, but its intensity is different. Based on Table 4, there is a positive correlation between the quantity, quality and timeliness of information and the source credibility, individually, and consumer confidence. A high correlation (the value of the correlation coefficient being 0.634 ) is observed between the credibility of the source in electronic word-of-mouth communication and trust, whereas the correlation of the mean strength (the correlation coefficient value being 0.479 ) is observed between the quality of electronic wordof-mouth communication and consumer confidence. Also, there is a strong correlation between consumer confidence and purchase intention (the correlation coefficient being 0.668 ).

Table 3 The value of Cronbach's alpha coefficient

\begin{tabular}{lc}
\hline Variable & Cronbach's alpha \\
\hline Quantity & 0.878 \\
Quality & 0.924 \\
Timeliness of information & 0.813 \\
Source credibility & 0.880 \\
Trust & 0.876 \\
Purchase intention & 0.812 \\
\hline
\end{tabular}

Source: Authors

Table 4 The correlation matrix

\begin{tabular}{|l|c|c|c|c|c|c|}
\hline Variable & 1 & 2 & 3 & 4 & 5 & 6 \\
\hline Quantity & 1 & $0.652^{* *}$ & $0.526^{* *}$ & $0.589^{* *}$ & $0.599^{* *}$ & $0.555^{* *}$ \\
\hline Quality & $0.652^{* *}$ & 1 & $0.524^{* *}$ & $0.469^{* *}$ & $0.479^{* *}$ & $0.395^{* *}$ \\
\hline Timeliness of information & $0.526^{* *}$ & $0.524^{* *}$ & 1 & $0.546^{* *}$ & $0.598^{* *}$ & $0.597^{* *}$ \\
\hline Source credibility & $0.589^{* *}$ & $0.469^{* *}$ & $0.546^{* *}$ & 1 & $0.634^{* *}$ & $0.504^{* *}$ \\
\hline Trust & $0.599^{* *}$ & $0.479^{* *}$ & $0.598^{* *}$ & $0.634^{* *}$ & 1 & $0.668^{* *}$ \\
\hline Purchase intention & $0.555^{* *}$ & $0.395^{* *}$ & $0.597^{* *}$ & $0.504^{* *}$ & $0.668^{* *}$ & 1 \\
\hline
\end{tabular}

Source: Authors 
In order to examine the common influence of the observed variables on consumer trust in electronic word-of-mouth communication, a multiple regression analysis was used. Just before the presentation of the results of the conducted analysis, the starting assumptions had been tested as a prerequisite for the implementation of the analysis. The diagram of the diffusion of the standardized residuals showed that the results were approximately rectangularly distributed and that most results were piled up in the center, which means that the assumption of linearity is not deformed. Apart from the assumption related to the size of the sample, which was met, normality and homoscedasticity had been examined prior to applying a regression analysis in the Eviews 9 program. When testing the normality of the residual deviations are concerned, the Jarque-Bera test was done. The value of the statistics of this test is 0.189299 , and $p=0.91>\alpha=0.05$, which implies that the empirical arrangement can be approximated by a normal one. The model also examined the homoscedasticity of the residual deviations. The value of the $\mathrm{F}$ statistics is 1.914933, $\mathrm{p}=0.11>0.05$, which indicates that there is no heteroscedasticity in the examined regression model.

After the examination of the initial assumptions, the multiple regression model was applied, where the dependent variable was trust, and the independent variables were the quantity, quality and timeliness of information and the source credibility. The model indicators are shown in Table 5.

Table 5 The indicators of the multiple-regression model

\begin{tabular}{ccccc}
\hline$R$ & $\begin{array}{c}\text { Adj.R } \\
\text { Square }\end{array}$ & St. error & $F$ & Sig \\
\hline 0.729 & 0.516 & 0.41517 & 33.770 & 0.000 \\
\hline
\end{tabular}

Source: Authors

The observed model is representative ( $\mathrm{Sig}=0.000)$, the value of the adjusted determination coefficient is 0.516 , which shows that $51.6 \%$ of the variability of the dependent variable of trust is explained by the four independent variables. Having in mind the fact that multiple-regression analysis often causes the problem of multicollinearity, a variance inflation factor - VIF is shown. Its value, which is lower than 5 , for all the variables shown confirms that there is no multicollinearity problem in the regression model (Table 6). By looking at the results in Table 6, it can be noted that the variable of the source credibility in electronic word-of-mouth communication individually contributes to the trust of the users of the wellness offer $(\beta=0.327)$, only to be followed by the timeliness of information in electronic wordof-mouth communication $(ß=0.280)$, as well as the quantity of information $(B=0.247)$. The variables of the quantity and timeliness of information and the source credibility make a unique contribution to the predictions of the dependent variables, i.e. trust, whereas this is not the case when the quality of electronic word-of-mouth communication is in question $(\mathrm{p}>0.05)$.

Table 6 The results of the multiple regression analysis (the dependent variable is trust)

\begin{tabular}{c|cccc}
\hline Variable & $\beta$ & T & Sig. & VIF \\
\hline Quantity & 0.247 & 2.683 & 0.008 & 2.159 \\
Quality & 0.018 & 0.205 & 0.838 & 1.890 \\
$\begin{array}{c}\text { Timeliness of } \\
\text { information }\end{array}$ & 0.280 & 3.456 & 0.001 & 1.672 \\
$\begin{array}{c}\text { Source } \\
\text { credibility }\end{array}$ & 0.327 & 3.955 & 0.000 & 1.738 \\
\hline
\end{tabular}

Source: Authors

Based on the regression analysis applied, the following hypotheses were confirmed: H1, H3 and $\mathrm{H} 4$, whereas $\mathrm{H} 2$ cannot be accepted.

The following steps in the research study involve conducting simple regression analysis, where the independent variable is consumer trust, and the dependent variable is purchase intentions regarding the use of wellness content. The indicators of the applied regression model are accounted for in Table 7. 
Table 7 The results of the simple regression analysis (the dependent variable is purchase intention)

\begin{tabular}{cccccc}
\hline $\begin{array}{c}\text { Adj.R } \\
\text { Square }\end{array}$ & $F$ & $\operatorname{Sig}(\mathrm{F})$ & $B$ & $\mathrm{~T}$ & Sig. \\
\hline 0.441 & 98.166 & 0.000 & 0.668 & 9.908 & 0.000 \\
\hline
\end{tabular}

Source: Authors

As can be seen, the presented model is representative, the adjusted determination coefficient 0.441 showing that $44.1 \%$ of the variability of variable purchase intention is explained by the 'trust' variable. Also, based on the value of $B=0.668$ and $p=0.000$, it can be concluded that the impact of trust in electronic wordof-mouth communication on purchase intention regarding the use of wellness packages is very strong. Based on everything previously stated, H5 can be confirmed.

\section{CONCLUSION}

The permeation of Internet technologies into almost all aspects contributes to the fact that the classic marketing communication instruments that shape purchasing behavior have significantly changed. Hence, instead of the traditional forms, the focus is placed on contemporary ones, such as electronic word-of-mouth communication. The role of electronic word-of-mouth communication, especially in the tourism sector, is very important and largely determines consumer purchase intention. By reducing risk and uncertainty, electronic word-ofmouth communication is one of the crucial sources of information. As is emphasized in the paper, electronic word-of-mouth communication in the wellness industry is one of the determining factors when the purchasing behavior of the users of these tourist arrangements is concerned. Starting from the primary goal set in the paper, the authors' intention was to examine whether the variables related to the quality, quantity and timeliness of information and the source credibility have an impact on consumer trust in electronic word-of-mouth or not, and also to determine whether the trust of the users of wellness packages contributes to purchasing behavior.

Based on the conducted empirical research, it was noticed that the quantity of information, the timeliness of information and the source credibility of messages in electronic word-of-mouth communication have a positive impact on consumer trust, which is in accordance with the previous research (Xiaorong, Bin, Qinghong, Liuli \& Yu, 2011, Coursaris, Van Osch \& Albini, 2017, Wu, Chen \& Chung, 2010), whereas the quality of information does not have a statistically significant impact. According to the conclusions reached by other researchers, customer confidence significantly determines purchase intention (Prasad et al, 2017). The creators of a tourist offer, especially wellness packages, should create a possibility of exchanging information among users because it provides a higher level of trust than the data provided by the company itself do. The social justification for the research refers to the possibility that both companies and consumers in the field of using wellness packages affect the trust of other users in the communication process.

Empirical research refers to certain managerial implications. This type of analysis can help the development of the tourism sector, i.e. the wellness industry to be more precise, the acceleration of electronic word of mouth communication and the analysis of consumer behavior in the online environment. Encouraging users to share information in this way would be of a greater benefit to both wellness and content creators. Increasing the availability of current online reviews increases consumer confidence, which very often is the key to successful market positioning.

The limitations of the conducted empirical research primarily refer to the fact that it was carried out in the territory of the City of Kragujevac, so in the following research the territory to be examined should be expanded. Then, in one of the next research steps, the forms of social media in electronic commerce that have a dominant influence on consumer behavior in electronic word-of-mouth communication and 
whether users show different preferences for different types of wellness tourism offers or not should be defined. Having in mind the fact that, depending on the profile of the respondents, the readiness for electronic word-of-mouth communication differs, whether there are statistically significant differences between younger and older respondents and their purchasing behavior should be subjected to examination.

\section{ACKNOWLEDGMENT}

This paper is part of an interdisciplinary research project (no. 41010), funded by the Ministry of Education, Science and Technological Development of the Republic of Serbia.

\section{REFERENCES}

Abdelaziz, M., Aziz, W., Khalifa, G., \& Ma'youf, M. (2015). Determinants of electronic word of mouth (eWOM) influence on hotel customers' purchase decision. Journal of Faculty of Tourism and Hotels, 9(2/2), 194-221.

Abubakar, A. M. (2016). Does eWOM influence destination trust and travel intention: A medical tourism perspective. Economic Research, 29(1), 598-611. doi:10.1080/133167 7X.2016.1189841

Albarq. A. (2014). Measuring the impacts of online word-ofmouth on tourists' attitude and intentions to visit Jordan: An empirical study. International Business Research, 7(1), 1422. doi:10.5539/ibr.v7n1p14

Alfina, I., Ero, J., Hidayanto, A., \& Shihab, M. (2014). The impact of cognitive trust and eWOM on purchase intention in C2C e-commerce site. Journal of Computer Science, 10(12), 2518-2524. doi:10.3844/jcssp.2014.2518.2524

Belarmino, A. M., \& Koh, Y. (2018). How eWOM motivations vary by hotel review website. International Journal of Contemporary Hospitality Management, 30(8), 1-22. doi.org/10.1108/IJCHM-02-2017-0055
Bellman, S., Johnson, E., Loshe, G., \& Mandel, N. (2006). Designing marketplaces of the artificial with consumers in mind. Journal of Interactive Marketing, 20(1), 21-33. doi.org/10.1002/dir.20053

Casaló, L. V., Flavián, C., \& Guinaliu, M. (2011). Understanding the intention to follow the advice obtained in an online travel community. Computers in Human Behavior, 27(2), 622633. doi:10.1016/j.chb.2010.04.013

Coulter, K., \& Coulter, R. (2002). Determinants of trust in a service provider: The moderating role of length of relationship. Journal of Services Marketing, 16(1), 35-50. doi:10.1108/08876040210419406

Coursaris, K., Van Osch, W., \& Albini, A. (2017). Antecedents and consequents of trustworthiness in user-generated online reviews: A case of the travel industry. SIGHCI 2017 Proceedings.

Curras-Perez, R., Ruiz, C., Sanchez-Garcia, I., \& Sanz, S. (2017). Determinants of customer retention in virtual environments. The role of perceived risk in a tourism services context. Spanish Journal of Marketing - ESIC, 21(2), 131-145. doi.org/10.1016/j.sjme.2017.07.002

Fan, Y. W., \& Miao, Y. F. (2012). Effect of electronic word-ofmouth on consumer purchase intention: The perspective of gender differences. International Journal of Electronic Business Management, 10(3), 175-181.

Fan, Y. W., Miao, Y. F., Fang, Y. H. \& Lin. R. Y. (2013). Establishing the adoption of electronic word-of-mouth through consumers' perceived credibility. International Business Research, 6(3), 58-65. doi:10.5539/ibr.v6n3p58

Flavián, C., Guinalíu, M., \& Gurrea, R. (2006). The role played by perceived usability, satisfaction and consumer trust on website loyalty. Information \& Management, 43(1), 1-14. doi:10.1016/j.im.2005.01.002

Fu, X., Bin, Z., Qinghong, X., Liuli, X., \& Yu, C. (2011). Impact of quantity and timeliness of eWOM information on consumer's online purchase intention under $\mathrm{C} 2 \mathrm{C}$ environment. Asian Journal of Business Research, 1(2), 37-52.

Gommans, M., Krishnan, K., \& Scheffold, K. (2001). From brand loyalty to e-loyalty: A conceptual framework. Journal of Economic and Social Research, 3(1), 43-58. 
Hennig-Thurau, T., \& Walsh, G. (2003). Electronic word-ofmouth: Motives for and consequences of reading customer articulations on the internet. International Journal of Electronic Commerce, 8(2), 51-74. doi.org/10.1080/10864415.20 03.11044293

Hennig-Thurau, T., Gwinner, K. P., Walsh, G., \& Gremler D. (2004). Electronic word-of-mouth via consumer-opinion platforms: What motivates consumers to articulate themselves on the internet. Journal of Interactive Marketing, 18(1), 38-52. doi.org/10.1002/dir.10073

Hu, N., Bose, I., Koh, N. S., \& Liu, L. (2012). Manipulation of online reviews: An analysis of ratings, readability, and sentiments. Decision Support Systems, 52(3), 674-684. doi:10.1016/j.dss.2011.11.002

Kimery, K. M., \& McCord, M. (2002) .) Third-party assurances: Mapping the road to trust in e-retailing. Journal of Information Technology Theory and Application, 4(2), 64-82.

Koncul, N. (2012). Wellness: A new mode of tourism. Economic Research, 25(2), 525-534. doi.org/10.1080/133167 7X.2012.11517521

Kursan, Milaković, I., Mihić, M., \& Ivasečko, N. (2017). Antecedents of traditional and electronic word of mouth communication: Student population based study. Mostariensia, 21(1), 97-111.

Lin, C., Wu, Y., \& Chen, J. (2013). Electronic word-of-mouth: The moderating roles of product involvement and brand image. Paper presented an the International conference on technology innovation and Industrial Management, Phuket, Thailand.

Lopez, M., \& Sicilia, M. (2014). Determinants of eWOM influence: The role of consumers' internet experience. Journal of Theoretical and Applied Electronic Commerce Research, 9(1), 28-43. doi:10.4067/s0718-18762014000100004

Marić, D., Kovač Žnideršić, R., Paskaš, N., Jevtić, J. i Kanjuga, Z. (2017). Savremeni potrošači elektronska interpersonalna komunikacija. Marketing, 48(3), 147-154. doi:10.5937/ Markt1703147M

Marinković, V., Senić, V., Obradović, S., \& Šapić, S. (2012). Understanding antecedents of customer satisfaction and word-of-mouth communication: Evidence from hypermarket chains. African Journal of Business Management, 6(29), 8515-8524. doi:10.5897/AJBM11.1455
Mueller, H., \& Kaufmann, E. (2001). Wellness tourism: Market analysis of a special health tourism segment and implications for the hotel industry. Journal of Vacation Marketing, 7(1), 7-15. doi.org/10.1177/135676670100700101

Nunnally, J. C. (1978). Introduction to Psychological Measurement. New York, NY: McGraw-Hill.

Prasad, S., Gupta, I., \& Totala, N. (2017). Social media usage, electronic word of mouth and purchase-decision involvement. Asia-Pacific Journal of Business Administration, 9(2), 134-145. doi.org/10.1108/APJBA-06-2016-0063

Republički zavod za statistiku. (2018). Upotreba informacionokomunikacionih tehnologija u Republici Srbiji. Preuzeto 11. januara 2019 sa http://publikacije.stat.gov.rs/G2018/Pdf/ G201816013.pdf

Sa'ait, N., Kanyan, A., \& Fitri Nazrin, M. (2016). The effect of ewom on customer purchase intention. International Academic Research Journal of Social Science, 2(1), 73-80.

Sapic, S. (2017). The effects of Cosmopolitanism and Tradition on the Evaluation and Intentions of the Users of Fast Food Restaurants. Economic Horizons, 19(2), 83-95. doi:10.5937/ ekonhor1702081S

Senić, R. i Senić, V. (2008). Menadžment i marketing usluga. Kragujevac, Republika Srbija: Prizma.

Shuqair, S., Cragg, P., Zaidan, A., \& Mitchell, T. (2016). The influence of users generated content on attitude towards brand and purchase intentions - Case of Bahrain. International Journal of Business Marketing and Management, 1(5), 9-20.

Stanković, Lj. i Đukić, S. (2014). Marketing komuniciranje. Niš, Republika Srbija: Ekonomski fakultet Univerziteta u Nišu.

Težak Damijanić, A., \& Šergo, Z. (2014). Determining travel motivations of wellness tourism. Ekonomska misao i praksa, $1,3-20$.

Trusov, M., Bucklin, R. E., \& Pauwels, K. (2009). Effects of word-of-mouth versus traditional marketing: Findings from an internet social networking site. Journal of Marketing, 73(5), 90-102. doi.org/10.1509/jmkg.73.5.90 
Wu, J., Chen, Y., \& Chung, Y. (2010). Trust factors influencing virtual community members: A study of transaction communities. Journal of Business Research, 63(9-10), 10251032.

Xiaorong, F., Bin, Z., Qinghong, X., Liuli, X., \& Yu, C. (2011). Impact of quantity and timeliness of eWOM information on consumer's online purchase intention under $\mathrm{C} 2 \mathrm{C}$ environment. Asian Journal of Business Research, 1(2), 3-52.
Zainal, N. T. A., Harun, A., \& Lily, J. (2017). Examining the mediating effect of attitude towards electronic words-of mouth (eWOM) on the relation between the trust in eWOM source and intention to follow eWOM among Malaysian travelers. Asia Pacific Management Review, 22(1), 35-44. doi:10.1016/j.apmrv.2016.10.004

\section{Received on $31^{\text {st }}$ January 2019, after revision, accepted for publication on $17^{\text {th }}$ April 2019 \\ Published online on $25^{\text {th }}$ April 2019}

Milan Kocic is an associate professor at the Faculty of Economics at the University of Kragujevac where he obtained his $\mathrm{PhD}$ in Marketing. He is engaged in the subjects of marketing, market communication and direct marketing in the bachelor studies, and also in marketing management and strategic marketing, in the master's or doctoral studies. The main area of his interest is marketing, branding and marketing communications.

Katarina Radakovic is a teaching assistant at the Faculty of Economics at the University of Kragujevac. She finished her bachelor and master studies at the same faculty, and is currently a $\mathrm{PhD}$ student. She is giving practical lectures in the subjects of marketing, market communication and direct marketing. The most important areas of her research are marketing and consumer behavior. 


\title{
IMPLIKACIJE ELEKTRONSKE INTERPERSONALNE KOMUNIKACIJE ZA IZBOR WELLNESS PONUDE
}

\author{
Milan Kocić* i Katarina Radaković \\ Ekonomski fakultet Univerziteta u Kragujevcu
}

U uslovima dinamičnog razvoja informaciono-komunikacionih tehnologija, značajno je izmenjen tradicionalni način uspostavljanja komunikacije među potrošačima. Usmena komunikacija, kao jedan od bitnih marketinških instrumenata, dobija novu dimenziju, posredstvom digitalnih oblika komuniciranja. Imajući u vidu značaj društvenih medija za formiranje stavova i namera potrošača u pogledu procesa kupovine, cilj rada je dolaženje do relevantnih saznanja o uticaju elektronske interpersonalne komunikacije na ponašanje potrošača. Preciznije rečeno, primenom korelacione i višestruke regresione analize ispitano je da li kvantitet, kvalitet, vremenska zasnovanost informacija i kredibilitet izvora elektronske interpersonalne komunikacije utiču na poverenje potrošača u oblasti wellness ponude. Jednodimenzionalna regresiona analiza primenjena je kako bi se utvrdilo da li poverenje potrošača doprinosi kupovnoj nameri. Rezultati sprovedenog empirijskog istraživanja ukazuju na to da postoji statistički značajan uticaj elektronske interpersonalne komunikacije na poverenje potrošača, kao i da poverenje potrošača pozitivno utiče na nameru o kupovini kada je u pitanju izbor wellness sadržaja $u$ Republici Srbiji.

Ključne reči: elektronska interpersonalna komunikacija, stavovi potrošača, kupovno ponašanje, društveni mediji, wellness ponuda

JEL Classification: M31, D830, 10

\section{UVOD}

U okvirima ponašanja potrošača, koje karakteriše veliki dinamizam, tradicionalni oblici marketinških komunikacija gube na svojoj efektivnosti (Trusov, Bucklin \& Pauwels, 2009), pa se upravo usmena, odnosno WOM (word of mouth) komunikacija

\footnotetext{
* Korespondencija: M. Kocić, Ekonomski fakultet Univerziteta u Kragujevcu, Liceja Kneževine Srbije 3, 34000 Kragujevac, Republika Srbija; e-mail: mkocic@kg.ac.rs
}

navodi kao moćan marketinški instrument. Proces komunikacije "od usta do usta" (word of mouth) podrazumeva usmenu komunikaciju između pošiljaoca i primaoca, koja se odnosi na proizvod, marku ili uslugu (Senić i Senić, 2008). Kao jedan od najstarijih oblika informisanja u procesu traženja, izbora i korišćenja proizvoda ili usluga, usmena komunikacija omogućava prenošenje iskustava u kupovini drugim ljudima (Stanković i Đukić, 2014). U novije vreme, kao posledica nastojanja preduzeća da se pozicioniraju na konkurentnom 
tržištu, gotovo da ne postoji privredni subjekt koji u svojoj poslovnoj strategiji ne koristi neki od oblika digitalnog marketinga, pa se i područje komunikacije proširuje na online okruženje. Zbog toga se klasična WOM komunikacija sve više zamenjuje elektronskom interpersonalnom komunikacijom. Sve veći broj potrošača svoju odluku o kupovini donosi na osnovu informacija koje kreiraju i plasiraju drugi potrošači u online okruženju (Hu, Bose, Koh \& Liu, 2012). Naime, sa intenziviranjem upotrebe internet tehnologija, menja se način na koji ljudi čitaju, pišu, prikupljaju informacije i dele iskustva (Casaló, Flavián \& Guinalíu, 2011). Prema istraživanjima, u Republici Srbiji (RS), $72,9 \%$ domaćinstava poseduje internet priključak, što je povećanje od 4,9\% u odnosu na 2017, a 8,2\% u odnosu na 2016. godinu. Približno 73\% koristilo je internet $u$ poslednja 3 meseca (Republički zavod za statistiku, 2018). U virtuelnim zajednicama ljudi razmenjuju iskustva, uspostavljaju prijateljstva i dele informacije (Wu, Chen \& Chung, 2010). Upravo zbog toga, posebno u turističkom sektoru, uloga elektronske interpersonalne komunikacije je sve veća. Intenzivna primena prvenstveno se reflektuje na uslužni sektor i utiče na kupovno ponašanje potrošača prilikom izbora turističkih ponuda i smeštajnih kapaciteta (Sa'ait, Kanyan \& Fitri Nazrin, 2016). Potencijalni korisnici određenih turističkih destinacija sprovode cost/benefit analizu alternativnih destinacija, pri čemu se, kao jedan od eksternih izvora informisanja, koristi elektronska interpersonalna komunikacija (Abubakar, 2016). U radu će uticaj elektronske interpersonalne komunikacije biti testiran u okvirima društvenih medija, ne uvažavajući specifičnosti svakog od njih. Dakle, pod pojmom društvenih medija u kontekstu sprovođenja istraživanja podrazumevaće se brojni sadržaji na internetu, kao što su forumi, blogovi, sajtovi za razmenu iskustava i svi drugi virtuelni oblici koji dorinose potenciranju komunikacije među potrošačima.

Predmet rada je ispitivanje uticaja elektronske interpersonalne komunikacije, posredstvom karakteristika poruke, kao i izvora poruke na stvaranje poverenja i povećanje namere kupovnog ponašanja kada je u pitanju wellness ponuda. Imajući u vidu specifičnost wellness sadržaja, kao jednog od savremenih vidova turizma, analizom relevantne literature došlo se do zaključaka da ne postoji dovoljan broj istraživanja koja tangiraju pitanja elektronske interpersonalne komunikacije $u$ ovoj oblasti. S obzirom na pokazatelje koji ukazuju na trend porasta wellness ponude, prilikom analize ovog problemskog područja marketinški potencijali su od izuzetnog značaja. Kako se za wellness aktivnosti izdvajaju sve veći budžeti, ova oblast, svakako, doprinosi razvoju turističke ponude. Oslanjajući se na već identifikovanu vezu između elektronske interpersonalne komunikacije i kupovnog ponašanja potrošača u turističkoj ponudi (Albarq, 2014), biće realizovano istraživanje na teritoriji RS. Neki od specifičnih ciljeva istraživanja, su sledeći:

- ispitati da li kvantitet, kvalitet i vremenska zasnovanost informacija u elektronskoj interpersonalnoj komunikaciji utiču na poverenje potrošača prema wellness sadržajima;

- doći do relevantnih saznanja o tome da li karakteristike izvora poruke u elektronskoj interpersonalnoj komunikaciji, preciznije kredibilitet, utiču na poverenje potrošača prema wellness sadržajima;

- utvrditi da li između poverenja potrošača i kupovne namere prilikom izbora wellness ponude postoji statistički značajan uticaj.

Teorijsko-metodološki instrumentarijum u radu podrazumeva primenu metoda analize i sinteze, kao i deskriptivno proučavanje i interpretaciju rezultata. Takođe, primenjen je anketni metod $u$ cilju sprovođenja empirijskog istraživanja. Kako bi se testirale definisane hipoteze, korišćena je analiza pouzdanosti, korelaciona analiza, kao i višestruka i prosta regresiona analiza.

Rad je strukturiran na takav način da se, nakon uvodnih razmatranja, primenom analize sadržaja eleboriraju teorijski pojmovi koji se tiču osnovnih trendova u oblasti wellness turizma, kao i varijable koje dominantno opredeljuju elektronsku interpersonalnu komunikaciju. U skladu sa postojećim teorijskim pregledom i rezultatima prethodnih istraživanja, $\mathrm{u}$ ovom delu rada formulisane su hipoteze. U narednoj celini prikazan je metodološki okvir, definisan 
konceptualni model istraživanja i elaborirani su rezultati empirijskog istraživanja. $\mathrm{U}$ okviru poslednje istraživačke celine data su zaključna razmatranja, kao i ograničenja i budući pravci karakteristični za problem istraživanja.

Originalnost i vrednost istraživanja proizlaze iz činjenice da na teritoriji RS ne postoji dovoljan broj radova koji se odnose na ispitivanje pojedinačnih varijabli elektronske interpersonalne komunikacije $\mathrm{u}$ datoj oblasti. Iako se prethodnim istraživačkim okvirima ispituje uloga ovog oblika komunikacije generalno, wellness industrija je bez sumnje tema koja je sa ovog aspekta nedovoljno istražena.

\section{PREGLED LITERATURE}

\section{Karakteristike wellness turizma}

Kao relativno nova forma zdravstvenog turizma (Težak Damijanić \& Šergo, 2014), wellness industrija okupira sve veću pažnju marketinških stručnjaka. Wellness sadržaji odnose se na proaktivnu stranu korisnika, uključujući njihove stavove $u$ vezi sa prevencijama oboljenja, potenciranjem zdravlja i održavanjem kvaliteta života. Prema H. Mueller-u i E. Kaufmann-u (2001), wellness podrazumeva "stanje zdravlja koje karakteriše harmonija tela, uma i duha, odgovornost prema samom sebi, fizička aktivnost, briga o lepoti, zdrava ishrana, relaksiranje, meditacija, mentalna aktivnost, obrazovanje, osećanje za okolinu i društvene veze".

$S$ obzirom na intenziviranje ulaganja $u$ wellness sadržaje u RS, počev od prvog wellness centra 2005, u Vrnjačkoj Banji, od ključnog značaja je razmotriti na koji način savremene tendencije $\mathrm{u}$ marketingu, kao što je elektronska interpersonalna komunikacija utiču na izbor potrošača. Najznačajniije distribucione kanale u oblasti wellness turizma predstavljaju upravo kanali komunikacije posredstvom interneta, zbog čega je potencijal za komercijalizaciju korišćenjem online platformi oblast koja ima dosta prostora za istraživanje. Imajući u vidu to da je cilj wellness ponude, prevashodno, unapređenje kvaliteta života i ostvarivanje harmonije, pre nego klasično izlečenje (Koncul, 2012), ovaj vid turizma može biti podoban za elektronsku interpersonalnu komunikaciju među potencijalnim ili aktuelnim korisnicima. Potencijalni korisnici turističkih sadržaja oslanjaju se na informacije iz online okruženja, s obzirom da turistički proizvod nije dostupan sve do trenutka samog korišćenja, pa je i veći rizik i nesigurnost (Abubakar, 2016).

\section{Konceptualne osnove elektronske interpersonalne komunikacije}

Danas, $\mathrm{u}$ eri razvoja informacione i komunikacione tehnologije, klasična usmena komunikacija analizira se posredstvom digitalnog ambijenta. $\mathrm{S}$ obzirom na sve veći broj korisnika interneta, privredni subjekti u brojnim oblastima prepoznali su značajne mogućnosti koje digitalizacija sa sobom donosi. Primena digitalnih sadržaja više nije pitanje izbora, već pitanje nužnosti koje neretko predstavlja i ključ egzistencije na sve konkurentnijem tržištu. Elektronska interpersonalna komunikacija definiše se kao "bilo koja pozitivna ili negativna izjava od strane potencijalnog, aktuelnog ili budućeg potrošača o proizvodima ili kompanijama koja omogućava razmenu stavova između pojedinaca ili institucija posredstvom internet platformi" (Hennig-Thurau \& Walsh, 2003).

Elektronska interpersonalna komunikacija može se realizovati u kompletnom digitalnom ambijentu, bilo da je reč o društvenim mrežama, sajtovima za deljenje interaktivnih sadržaja, mikroblogovima, forumima i svim drugim oblicima koji doprinose razmeni iskustava, mišljenja i stavova korisnika različitih proizvoda i usluga. Uticaj elektronske interpersonalne komunikacije na kupovno ponašanje potrošača predmet je brojnih istraživanja (Fan \& Miao, 2012; Prasad \& Gupta, 2016). Ovaj oblik razmene iskustva i saznanja potrošača u značajnoj meri opredeljuje kupovno ponašanje (Marinković, Senić, Obradović \& Šapić, 2012). Zbog toga je, za kreatore marketinških strategija i taktika, od izuzetne važnosti da na pravi način sagledaju značaj i potencijale ovog oblika komunikacije. 
Olakšana dostupnost online komentara, kao i anonimnost prilikom razmene stavova i iskustava, samo su još neki od faktora koji potenciraju značaj elektronske interpersonalne komunikacije u odnosu na tradicionalnu komunikaciju u offline okruženju (Bellman, Johnson, Loshe \& Mandel, 2006). Kao jedna od presudnih karakteristika, na kojima se zasniva prednost elektronske interpersonalne komunikacije, navodi se to što, $\mathrm{u}$ odnosu na tradicionalnu komunikaciju, ona nije ograničena na mali broj učesnika, već je njen doseg izuzetno veliki i može obuhvatiti značajan broj online korisnika (HennigThurau, Gwinner, Walsh \& Gremler, 2004). Prema nekim istraživanjima (Xiaorong, Bin, Qinghong, Liuli \& Yu, 2011), elektronska interpersonalna komunikacija, u mnogome, smanjuje nepoverenje potrošača povezano sa online kupovinom, koje može nastati usled percipiranog rizika, ili nedovoljnih i asimetričnih informacija. U radu će se, kao ključni kriterijumi koji karakterišu informacije koje se plasiraju posredstvom elektronske interpersonalne komunikacije, navesti neki koje su, najčešće, predmet analiza. To su kvalitet poruke, kvantitet i vremenska zasnovanost.

\section{Kvantitet informacija $u$ elektronskoj interpersonalnoj komunikaciji}

S obzirom na neopipljivu prirodu proizvoda ili usluga u virtuelnom okruženju, prilikom izbora potrošača veoma je važno da na raspolaganju imaju što veći broj informacija, odnosno, komentara koji bi smanjili njihov rizik prilikom donošenja odluke. Jedna od varijabli koje se ispituju u radu jeste kvantitet informacija. Polazeći od prethodnih istraživanja, ispitaće se da li veća količina dostupnih informacija u elektronskoj interpersonalnoj komunikaciji pojačava poverenje potrošača i utiče na odluku o izboru određene wellness ponude. Prema istraživanjima koja tangiraju datu oblast, poverenje potrošača se intenzivira ukoliko u okviru elektronske interpersonalne komunikacije što veći broj korisnika ostavi komentar (Xiaorong, Bin, Qinghong, Liuli \& Yu, 2011). Zbog toga će se, u cilju ispitivanja ove varijable prilikom izbora wellness ponude testirati prva hipoteza:
H1: Kvantitet informacija u elektronskoj interpersonalnoj komunikaciji ima pozitivan i statistički značajan uticaj na poverenje korisnika prilikom izbora wellness ponude.

\section{Kvalitet informacija u elektronskoj interpersonalnoj komunikaciji}

Varijabla koja je najčešće neodvojivi deo istraživanja, uporedo sa kvantitetom informacija, je kvalitet elektronske interpersonalne komunikacije. Još $u$ radovima iz ranijeg perioda, kvalitet informacija definisan je kao značajan pokazatelj uspeha informacionih sistema (Fan, Miao, Fang \& Lin, 2013). Većina autora ima jedinstveni stav da je kvalitet informacija jedna od ključnih determinanti koje usmeravaju odluku potrošača prilikom izbora određenog proizvoda ili usluge. Tako, na primer, Y. W. Fan et al (2013) ističu da je upravo kvalitet elektronske interpersonalne komunikacije faktor koji u najvećoj meri utiče na poverenje potrošača, kao i da su online komentari, koji sadrže dovoljno argumenata i činjenica, krucijalni za poverenje potrošača. Na osnovu navedenog teorijskog pregleda, definiše se i druga hipoteza:

H2: Kvalitet informacija u elektronskoj interpersonalnoj komunikaciji ima pozitivan i statistički značajan uticaj na poverenje korisnika prilikom izbora wellness ponude.

\section{Vremenska zasnovanost informacija $\mathbf{u}$ elektronskoj interpersonalnoj komunikaciji}

S obzirom na dinamičnu prirodu virtuelnog okruženja, potrošači su svakodnevno izloženi ažuriranim sadržajima koji su predmet njihovog interesovanja. Kao jedan od faktora, koji opredeljuju elektronsku interpersonalnu komunikaciju, navodi se vremenska dimenzija, odnosno, period kada je poruka online putem kreirana i upotrebljena od strane drugog potencijalnog korisnika. Pod vremenskom određenošću, podrazumeva se period koji protekne od momenta kada je korisnik ostavio komentar $\mathrm{u}$ elektronskoj interpersonalnoj komunikaciji do trenutka kada potencijalni korisnik konsultuje isti 
komentar prilikom svog izbora. Istraživanje koje je sprovedeno 2017, potvrđuje da što su komentari skorije postavljeni, to je veći stepen poverenja potencijalnih korisnika turističkih usluga (Coursaris, Van Osch \& Albini, 2017). U vezi sa tim, definisana je treća hipoteza:

H3: Vremenska zasnovanost informacija u elektronskoj interpersonalnoj komunikaciji ima pozitivan i statistički značajan uticaj na poverenje korisnika prilikom izbora wellness ponude.

\section{Kredibilitet izvora u elektronskoj interpersonalnoj komunikaciji}

Pored karakteristika poruke koje su obrazložene kroz tri navedene dimenzije, kredibilitet izvora elektronske interpersonalne komunikacije može biti jedna od determinanti poverenja potrošača (Lopez \& Sicilia, 2014). Ovo je jedna od varijabli koja ima pozitivan uticaj na kupovno ponašanje potrošača (Shuqair, Cragg, Zaidan \& Mitchell, 2016), što je potvrđeno i kroz istraživanje koje je sprovedeno na teritoriji Srbije, Hrvatske i Bosne i Hercegovine (Kursan, Milaković, Mihić \& Ivasečko, 2017). Zbog toga će se u radu, pored karakteristika informacija u elektronskoj interpersonalnoj komunikaciji, utvrditi kakav značaj na poverenje i kupovno ponašanje imaju izvori od kojih informacija dolazi u procesu izbora wellness ponude. Neki od faktora, koji imaju dominantan uticaj na poverenje potrošača, odnose se na kompetencije, iskrenost i dobrotvornost izvora poruke (Flavián, Guinalíu \& Gurrea, 2006; Casaló, Flavián \& Guinalíu, 2011). Cilj je da se ispita da li poverenje korisnika, kreirano posredstvom ovih varijabli, utiče na kupovno ponašanje prilikom izbora wellness ponude.

Što se tiče iskrenosti, ona se odnosi na uverenje da će drugi učesnici u elektronskoj interpersonalnoj komunikaciji održati svoju reč, ispuniti obećanje, odnosno da će biti iskreni prilikom komunikacije u online okruženju u odnosu na druge učesnike (Casaló, Flavián \& Guinalíu, 2011). Dobronamernost se odnosi na altruistički motiv i uključenost $\mathrm{u}$ elektronsku interpersonalnu komunikaciju, sa namerom da se pomognu i podrže, odnosno, da se pokaže briga za druge učesnike ( $\mathrm{Wu}, \mathrm{Chen} \mathrm{\&} \mathrm{Chung,} \mathrm{2010).} \mathrm{U} \mathrm{online}$ okruženju, članovi bi trebalo da odgovaraju na pitanja drugih korisnika i da proaktivno razmatraju koje su njihove želje i potrebe (Wu, Chen \& Chung, 2010). Kada govorimo o kompetentnosti ona je još jedna od varijabli koja utiče na poverenje potrošača. Definiše se kao percipirani nivo veština i znanja u procesu elektronske interpersonalne komunikacije od strane drugih učesnika (Coulter, Coulter, 2002).

Iako postoje brojna istraživačka pitanja kojima se proučava data oblast, u RS je neznatan broj istraživanja koja ispituju ovakve relacije. Između poverenja potrošača, determinisanog posredstvom ove tri dimenzije, i kupovnog ponašanja u oblasti turističke ponude, posebno izbora destinacija, postoji značajan uticaj (Curras-Perez, Ruiz, Sanchez-Garcia \& Sanz, 2017). Zbog toga bi preduzeća u turističkom sektoru trebalo da nastoje da povećaju poverenje potrošača u online okruženju.

H4: Kredibilitet izvora u elektronskoj interpersonalnoj komunikaciji ima pozitivan i statistički značajan uticaj na poverenje korisnika prilikom izbora wellness ponude.

\section{Poverenje i namera o kupovini}

U online okruženju proizvod se ne može dodirnuti, osetiti, i ne može se prodavac pogledati u oči (Gommans, Krishnan, \& Scheffold, 2001). Poverenje potrošača još je jedna od ključnih varijabli koje utiču na kupovno ponašanje potrošača (Alfina, Ero, Hidayanto \& Shihab, 2014). Kada je u pitanju elektronska interpersonalna komunikacija, poverenje predstavlja relevantan faktor koji determiniše odluku prilikom izbora, jer je elektronska pisana reč formalna i smatra se iskrenijom (Marić, Kovač Žnideršić, Paskaš, Jevtić i Kanjuga, 2017). Naime, ustanovljeno je da najviše uspeha u online okruženju imaju upravo oni sajtovi kojima potrošači najviše veruju (Prasad, Gupta \& Totala, 2017). Prema istraživanjima, postoji veći stepen poverenja u online komentare napisane od strane drugih korisnika ponude, u odnosu na one koji su napisani od strane stručnih lica (Belarmino \& Koh, 
2018). Zbog neopipljive prirode usluga u turističkom sektoru, većina korisnika svoj izbor zasniva na informacijama koje se plasiraju u elektronskoj interpersonalnoj komunikaciji K. M. Kimery i M. McCord (2002) ističu da poverenje u online okruženju pomaže u smanjenju rizika sa kojima se potrošač suočava.

Korišćenjem dubinskog intervjua, S. Prasad, I. Gupta i N. Totala (2017) objašnjavaju da se uticaj elektronske interpersonalne komunikacije na nameru o kupovini ostvaruje upravo posredstvom poverenja potrošača. U okviru marketinških istraživanja, namera u ponašanju odnosi se na visoku verovatnoću iskazivanja određene vrste ponašanja (Sapic, 2017). Namera o kupovini u online okruženju, koje karakteriše veći stepen neizvesnosti i rizika vrlo često je direktno uslovljena stepenom poverenja koje imaju potrošači. U skladu sa rezultatima prethodnih istraživanja, poverenje je direktno povezano sa kupovnim ponašanjem (Xiaorong, Bin, Qinghong, Liuli \& Yu, 2011).

H5: Poverenje korisnika u elektronskoj interpersonalnoj komunikaciji ima pozitivan i statistički značajan uticaj na kupovnu nameru prilikom izbora wellness ponude.

\section{METODOLOGIJA ISTRAŽIVANJA}

Polazeći od detaljnog elaboriranja teorijskih pojmova, u radu je sprovedeno empirijsko istraživanje. Predmet istraživanja odnosi se na ispitivanje povezanosti između elektronske interpersonalne komunikacije i poverenja korisnika, i analiziranje poverenja kao determinante kupovnog ponašanja prilikom izbora wellness ponude. U cilju prikupljanja podataka, korišćen je upitnik koji je distribuiran ispitanicima u klasičnoj formi, popunjavanjem anketnih listića na teritoriji Kragujevca. Anketiranje je sprovedeno korišćenjem prostog slučajnog uzorka, kroz direktan kontakt sa ispitanicima. Podeljeno je 150 upitnika, od čega je 124 validnih, što predstavlja visoku stopu odgovora (82,7\%). Empirijsko istraživanje realizovano je primenom metoda anketiranja u periodu avgustoktobar 2018. U cilju dobijanja validnih rezultata, podaci su filtrirani tako što su u razmatranje uzeti samo oni ispitanici koji su istakli da su prethodno koristili neke od wellness sadržaja u RS. Upitnik je strukturiran na takav način da sadrži, pre svega, opšte podatke, kao što su: pol, starost, školska sprema i radni status, a zatim konstatacije koje se vezuju za sve varijable koje se ispituju. Ispitanici su stepen slaganja sa konstatacijama navedenim u upitniku iskazivali putem petostepene Likert-ove skale (broj 1 - nimalo se ne slažem, broj 5 - apsolutno se slažem), koja je jedna od najčešće primenjivanih metoda za donošenje validnih zaključaka u ovoj vrsti istraživanja.

Promenljive koje su korišćene u upitniku merene su putem konstatacija koje su preuzete i adaptirane $\mathrm{u}$ skladu sa potrebama istraživanja. Konstatacije, vezane za kvantitet i kvalitet informacija u elektronskoj interpersonalnoj komunikaciji, prilagođene su i adaptirane prema (Lin, Wu, Chen, 2013). Vremenska zasnovanost informacija $\mathrm{u}$ elektronskoj interpersonalnoj komunikaciji, vrednovana je putem konstatacija koje su formulisane na osnovu autora (Sa'ait, Kanyan \& Fitri Nazrin, 2016), dok je kredibilitet izvora prilagođen prema konstatacijama (Kursan et al, 2017.) Poverenje potrošača vrednovano je putem konstatacija prilagođenih na osnovu istraživanja (Zainal, Harun \& Lily, 2017), dok je namera o kupovini $\mathrm{u}$ pogledu wellness sadržaja vrednovana putem konstatacija koje su adaptirane prema (Abdelaziz, Aziz, Khalifa \& Ma'youf, 2015). Kako bi se ispitao odnos između posmatranih varijabli, u radu su postavljene hipoteze testirane primenom deskriptivne statistike, analize pouzdanosti, korelacione analize, kao i proste i višestruke regresije. Uticaj četiri analizirane varijable na poverenje potrošača, ispitan je putem višestruke regresije, dok je uticaj poverenja na kupovno ponašanje, $\mathrm{u}$ pogledu izbora wellness sadržaja, ispitan putem proste regresione analize. Analiza podataka izvršena je u statističkom programu za društvene nauke SPSS (The Statistical Package for the Social Sciences) i Eviews. Uzimajući u obzir definisane varijable, $\mathrm{u}$ skladu sa teorijskim pregledom i postavljenim hipotezama, za potrebe istraživanja definisan je istraživački model (Slika 1). 


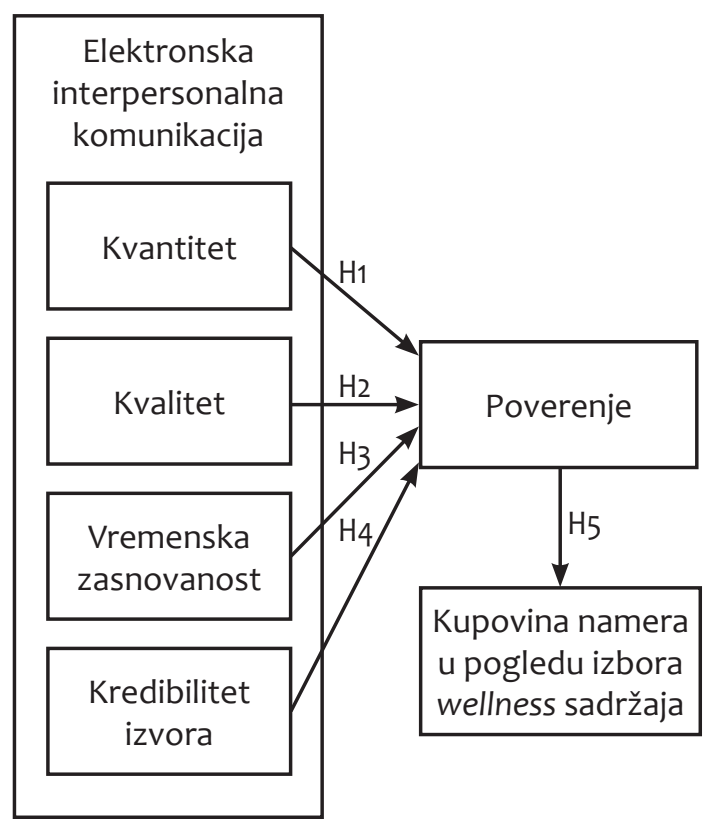

Slika 1 Konceptualni model istraživanja

Izvor: Autori

\section{REZULTATI ISTRAŽIVANJA}

Istraživanje je obuhvatilo 124 ispitanika, različitih demografskih profila (Tabela 1).

Na osnovu demografske strukture, može se uočiti da je veći procenat ispitanika ženskog pola (57,3\%). Što se tiče dimenzije koja se odnosi na starost ispitanih osoba, najviše je predstavnika koji pripadaju starosnoj kategoriji u rasponu 25-31 godine, dok je najmanje onih koji imaju preko 60 godina (7,3\%). Takođe, u Tabeli 1 se uočava da je najveći procenat ispitanika sa visokim obrazovanjem (40,3\%), kao i da je najviše službenika $(24,2 \%)$, a najmanje penzionera $(4,8 \%)$.

$\mathrm{U}$ početnim istraživačkim koracima, prikazani su rezultati analize deskriptivne statistike, kako bi se ispitala povoljnost i homogenost, odnosno, heterogenost stavova ispitanika. Na osnovu rezultata u Tabeli 2, može se uočiti da je vrednost aritmetičke sredine visoka za sve konstatacije, s tim da je najveća vrednost vezana za konstataciju koja se odnosi na to
Tabela 1 Demografska struktura ispitanika

\begin{tabular}{lcc}
\hline Demografski profil & Frekvencija & $\%$ \\
\hline Pol & & \\
\hline Muški & 53 & 42,7 \\
Ženski & 71 & 57,3 \\
\hline Starost & 16 & \\
\hline $18-24$ & 27 & 21,9 \\
$25-31$ & 20 & 16,1 \\
$32-38$ & 19 & 15,3 \\
$39-45$ & 16 & 12,9 \\
$46-52$ & 17 & 13,7 \\
$53-59$ & 9 & 7,3 \\
6o i više & & \\
\hline Obrazovanje & 2 & 1,6 \\
\hline Osnovno obrazovanje & 38 & 30,6 \\
Srednje obrazovanje & 34 & 27,4 \\
Više obrazovanje & 50 & 40,3 \\
Visoko obrazovanje & & \\
\hline Radni status & 14 & 11,3 \\
\hline Student & 26 & 21,0 \\
Menadžer, preduzetnik & 22 & 17,7 \\
Profesor, lekar, inženjer & 30 & 24,2 \\
Službenik & 26 & 21,0 \\
Radnik & 6 & 4,8 \\
Penzioner & &
\end{tabular}

Izvor: Autori

da je ispitanicima bitno da kvalitet online komentara bude visok (aritmetička sredina 4,48), dok je najniža vrednost aritmetičke sredine koja se tiče poverenja $\mathrm{u}$ online komentare date od strane drugih korisnika wellness sadržaja $(3,96)$. Što se tiče homogenosti stavova ispitanika, najveći stepen slaganja, odnosno, najniža vrednost standardne devijacije $(0,612)$, zabeležena je kod konstatacije koja se tiče namere o kupovini wellness sadržaja na osnovu informacija koje dobijaju online putem, dok je najveća heterogenost stavova ispitanika, odnosno, najveće odstupanje uočeno kod konstatacije vezane za iskaz da drugi korisnici u online komunikaciji daju korisne komentare kada je $\mathrm{u}$ pitanju izbor wellness ponude (standardna devijacija $0,743)$.

U cilju ispitivanja pouzdanosti i interne konzistentnosti konstatacija koje su definisane u radu, za sve posmatrane varijable izračunata je vrednost 
Tabela 2 Rezultati deskriptivne statistike za navedene konstatacije

\begin{tabular}{|c|c|c|}
\hline Konstatacija & $\begin{array}{c}\text { Aritmetička } \\
\text { sredina }\end{array}$ & $\begin{array}{c}\text { Standardna } \\
\text { devijacija }\end{array}$ \\
\hline \multicolumn{3}{|l|}{ Kvantitet } \\
\hline Što je veći broj online komentara, to je wellness ponuda popularniija. & 4,12 & 0,694 \\
\hline Što je veći broj online komentara, wellness ponuda ostvaruje veću prodaju. & 4,08 & 0,739 \\
\hline $\begin{array}{l}\text { Veliki broj visoko rangiranih komentara i preporuka u online okruženju pokazuju da wellness } \\
\text { ponuda ima dobru reputaciju. }\end{array}$ & 4,19 & 0,679 \\
\hline \multicolumn{3}{|l|}{ Kvalitet } \\
\hline Bitno mi je da online komentari u vezi sa wellness ponudama budu jasni. & 4,36 & 0,629 \\
\hline Bitno mi je da online komentari u vezi sa wellness ponudama budu razumljivi. & 4,42 & 0,613 \\
\hline Bitno mi je da online komentari u vezi sa wellness ponudama budu korisni. & 4,44 & 0,629 \\
\hline $\begin{array}{l}\text { Generalno, bitno mi je da kvalitet online komentara u vezi sa wellness ponudama bude } \\
\text { visok. }\end{array}$ & 4,48 & 0,631 \\
\hline \multicolumn{3}{|l|}{ Vremenska zasnovanost } \\
\hline Bitno mi je da online komentari korisnika wellness ponude budu što aktuelniji. & 4,21 & 0,641 \\
\hline $\begin{array}{l}\text { Bitno mi je da online komentari korisnika wellness ponude budu novijeg datuma, tj. u skladu } \\
\text { sa sadašnjim trendovima. }\end{array}$ & 4,25 & 0,670 \\
\hline Bitno mi je da online komentari korisnika wellness ponude budu ažurirani i validni. & 4,27 & 0,639 \\
\hline \multicolumn{3}{|l|}{ Kredibilitet izvora } \\
\hline $\begin{array}{l}\text { Prilikom izbora wellness ponuda, mogu da verujem informacijama koje dobijam od drugih } \\
\text { korisnika u online okruženju. }\end{array}$ & 4,06 & 0,695 \\
\hline $\begin{array}{l}\text { Verujem da drugi korisnici u online komunikaciji daju iskrene komentare o wellness } \\
\text { sadržajima. }\end{array}$ & 4,00 & 0,721 \\
\hline $\begin{array}{l}\text { Verujem da drugi korisnici u online komunikaciji daju korisne komentare o wellness } \\
\text { sadržajima. }\end{array}$ & 4,02 & 0,743 \\
\hline \multicolumn{3}{|l|}{ Poverenje } \\
\hline Učesnici u online komunikaciji su kompetentni kada diskutuju o wellness ponudi & 4,12 & 0,645 \\
\hline Većina drugih korisnika wellness sadržaja u online okruženju ne daje lažne komentare. & 4,02 & 0,715 \\
\hline $\begin{array}{l}\text { Smatram da mogu imati poverenja u online komentare date od strane drugih korisnika } \\
\text { wellness sadržaja. }\end{array}$ & 3,96 & 0,726 \\
\hline $\begin{array}{l}\text { Korisnici wellness sadržaja prilikom online komentara vode računa o potrebama drugih } \\
\text { članova. }\end{array}$ & 4,08 & 0,705 \\
\hline \multicolumn{3}{|l|}{ Namera o kupovini } \\
\hline Prethodni online komentari o wellness ponudi utiču na moju spremnost da rezervišem istu. & 4,27 & 0,629 \\
\hline $\begin{array}{l}\text { Kada smatram da je wellness ponuda dobra kao što je opisano u online komentarima, } \\
\text { spreman sam da rezervišem istu. }\end{array}$ & 4,33 & 0,634 \\
\hline Svoj izbor wellness ponude zasnivam na online komentarima koje sam pročitao. & 4,37 & 0,618 \\
\hline Informacije koje dobijam u online komunikaciji utiču na moj izbor wellness ponude. & 4,35 & 0,612 \\
\hline
\end{tabular}


Cronbach-ovog alfa koeficijenta. Kako je prihvatljiva vrednost ovog koeficijenta iznad 0,7 (Nunnally, 1978), na osnovu Tabele 3 može se zaključiti da sve navedene varijable ispunjavaju zadati kriterijum.

Tabela 3 Vrednost Cronbach alfa koeficijenta

\begin{tabular}{lc}
\hline Varijabla & Cronbach alfa \\
\hline Kvantitet & 0,878 \\
Kvalitet & 0,924 \\
Vremenska zasnovanost & 0,813 \\
Kredibilitet izvora & 0,880 \\
Poverenje & 0,876 \\
Namera o kupovini & 0,812 \\
\hline
\end{tabular}

Izvor: Autori

Nakon ispitivanja interne konzistentnosti, predstavljena je korelaciona matrica kako bi se ispitala jačina i smer veze između posmatranih varijabli. Sagledavanjem vrednosti Pearson-ovog koeficijenta, može se zaključiti da između svih promenljivih postoji korelacija, s tim da je ona različitog intenziteta. Na osnovu Tabele 4, uočava se da postoji pozitivna korelacija između kvantiteta, kvaliteta, vremenske zasnovanosti i kredibiliteta izvora, pojedinačno, i poverenja potrošača. Velika korelacija (vrednost koeficijenta korelacije 0,634) uočava se između kredibiliteta izvora u elektronskoj interpersonalnoj komunikaciji i poverenja, dok je korelacija srednje jačine (vrednost koeficijenta korelacije 0,479) uočena između kvaliteta elektronske interpersonalne komunikacije i poverenja potrošača. Takođe, između poverenja potrošača i namere o kupovini postoji jaka korelaciona veza (koeficijent korelacije iznosi 0,668).

Kako bi se ispitao zajednički uticaj posmatranih varijabli na poverenje potrošača u elektronskoj interpersonalnoj komunikaciji, korišćena je višestruka regresiona analiza. Neposredno pre prikazivanja rezultata sprovedene analize, testirane su polazne pretpostavke kao preduslov za njeno sprovođenje. Dijagram rasturanja standardizovanih reziduala pokazao je da su rezultati približno pravougaono raspoređeni i da je većina rezultata nagomilana $u$ centru, što znači da pretpostavka o linearnosti nije narušena. Pored pretpostavke o veličini uzorka, koja je zadovoljena, normalnost i, homoskedastičnost ispitani su pre primene regresione analize u programu Eviews. Kada se radi o testiranju normalnosti rezidualnih odstupanja, korišćen je Jarque-Bera test. Statistika ovog testa iznosi 0,189299, a $p=0,91>\alpha=0,05$, što implicira da se empirijski raspored može aproksimirati normalnim. U modelu je ispitana i homoskedastičnost rezidualnih odstupanja, korišćenjem Vrednost F statistike je 1,914933, $p=0,11$ > 0,05 , što ukazuje da $u$ ispitanom regresionom modelu ne postoji heteroskedastičnost.

Nakon ispitivanja polaznih pretpostavki, primenjen je model višestruke regresije, gde je zavisna varijabla poverenje, a nezavisne varijable su kvantitet, kvalitet, vremenska zasnovanost i kredibilitet izvora. Pokazatelji modela prikazani su u Tabeli 5.

Tabela 4 Korelaciona matrica

\begin{tabular}{lcccccc}
\hline Varijabla & 1 & 2 & 3 & 4 & 5 & 6 \\
\hline Kvantitet & 1 & $0,652^{* *}$ & $0,526^{* *}$ & $0,589^{* *}$ & $0,599^{* *}$ & $0,555^{* *}$ \\
Kvalitet & $0,652^{* *}$ & 1 & $0,524^{* *}$ & $0,469^{* *}$ & $0,479^{* *}$ & $0,395^{* *}$ \\
Vremenska zasnovanost & $0,526^{* *}$ & $0,524^{* *}$ & 1 & $0,546^{* *}$ & $0,598^{* *}$ & $0,597^{* *}$ \\
Kredibilitet izvora & $0,589^{* *}$ & $0,469^{* *}$ & $0,546^{* *}$ & 1 & $0,634^{* *}$ & $0,504^{* *}$ \\
Poverenje & $0,599^{* *}$ & $0,479^{* *}$ & $0,598^{* *}$ & $0,634^{* *}$ & 1 & $0,668^{* *}$ \\
Namera o kupovini & $0,555^{* *}$ & $0,395^{* *}$ & $0,597^{* *}$ & $0,504^{* *}$ & $0,668^{* *}$ & 1 \\
\hline
\end{tabular}

Izvor: Autori 
Tabela 5 Pokazatelji modela višestruke regresije

\begin{tabular}{ccccc}
\hline$R$ & $\begin{array}{c}\text { Adj. } R \\
\text { Square }\end{array}$ & $\begin{array}{c}\text { St. } \\
\text { greška }\end{array}$ & $F$ & Sig \\
\hline 0,729 & 0,516 & 0,41517 & 33,770 & 0,000 \\
\hline
\end{tabular}

Izvor: Izrada autora u SPSS-u

Posmatrani model je reprezentativan ( $\mathrm{Sig}=0,000)$, korigovana vrednost koeficijenta determinacije iznosi 0,516 , što pokazuje da je 51,6\% varijabiliteta zavisne promenljive poverenje objašnjeno putem četiri nezavisne varijable. Kako se prilikom primene višestruke regresione analize često javlja problem multikolinearnosti, prikazan je faktor rasta varijanse - VIF. Njegova vrednost niža od 5 za sve prikazane varijable potvrđuje da $u$ regresionom modelu ne postoji problem multikolinearnosti (Tabela 6). Sagledavanjem rezultata u Tabeli 6, uočava se da varijabla kredibilitet izvora u elektronskoj interpersonalnoj komunikaciji pojedinačno najviše doprinosi poverenju korisnika wellness ponude ( $\$$ $=0,327)$, nakon čega sledi vremenska zasnovanost poruka u elektronskoj interpersonalnoj komunikaciji $(ß=0,280)$, kao i kvantitet informacija $(B=0,247)$. Promenljive kvantitet, vremenska zasnovanost i kredibilitet izvora daju jedinstven doprinos predikciji zavisne promenljive, odnosno, poverenja, dok kod kvaliteta elektronske interpersonalne komunikacije to nije slučaj $(p>0,05)$.

Tabela 6 Rezultati višestruke regresione analize (zavisna promenljiva je poverenje)

\begin{tabular}{lcccc}
\hline Varijabla & $B$ & $T$ & Sig. & VIF \\
\hline Kvantitet & 0,247 & 2,683 & 0,008 & 2,159 \\
Kvalitet & 0,018 & 0,205 & 0,838 & 1,890 \\
$\begin{array}{l}\text { Vremenska } \\
\text { zasnovanost }\end{array}$ & 0,280 & 3,456 & 0,001 & 1,672 \\
$\begin{array}{l}\text { Kredibilitet } \\
\text { izvora }\end{array}$ & 0,327 & 3,955 & 0,000 & 1,738 \\
\hline
\end{tabular}

Izvor: Autori
Na osnovu primenjene regresione analize, potvrđene su hipoteze H1, H3 i H4, dok se hipoteza H2 odbacuje.

Naredni istraživački korak podrazumeva primenu proste regresione analize, gde je nezavisna promenljiva poverenje potrošača, a zavisna promenljiva kupovna namera u pogledu korišćenja wellness sadržaja. Pokazatelji primenjenog regresionog modela, prikazani su u Tabeli 7 .

Tabela 7 Rezultati proste regresione analize (zavisna promenljiva je kupovna namera)

\begin{tabular}{cccccc}
\hline $\begin{array}{c}\text { Adj.R } \\
\text { Square }\end{array}$ & $F$ & $\operatorname{Sig}(\mathrm{F})$ & $\beta$ & $\mathrm{T}$ & Sig. \\
\hline 0,441 & 98,166 & 0,000 & 0,668 & 9,908 & 0,000 \\
\hline
\end{tabular}

Izvor: Autori

Kao što se može uočiti, predstavljeni model je reprezentativan, prilagođeni koeficijent determinacije 0,441 pokazuje da je $44,1 \%$ varijabiliteta promenljive kupovna namera objašnjeno putem promenljive poverenje. Takođe, na osnovu vrednosti $B=0,668$ i $p=0,000$ može se zaključiti da je uticaj poverenja $\mathrm{u}$ elektronskoj interpersonalnoj komunikaciji na kupovnu nameru u pogledu korišćenja wellness sadržaja veoma jak. Na osnovu prethodno navedenog, može se potvrditi hipoteza H5.

\section{ZAKLJUČAK}

Prodiranje internet tehnologija $u$ gotovo sve aspekte, doprinosi tome da se i klasični instrumenti marketinške komunikacije, koji oblikuju kupovno ponašanje potrošača, značajno menjaju. Zbog toga se, umesto tradicionalnih oblika, akcenat stavlja na savremene, kao što je elektronska interpersonalna komunikacija. Uloga elektronske interpersonalne komunikacije, posebno u turističkom sektoru veoma je značajna i u velikoj meri determiniše kupovnu nameru potrošača. Smanjujući rizik i neizvesnost, elektronska interpersonalna komunikacija predstavlja jedan od krucijalnih izvora informisanja. Kao što je 
istaknuto $\mathrm{u}$ radu, $\mathrm{u}$ wellness industriji, elektronska interpersonalna komunikacija predstavlja jedan od determinišućih faktora kada je u pitanju kupovno ponašanje korisnika ovih turističkih sadržaja. Polazeći od osnovnog cilja u radu, namera autora bila je da se ispita da li varijable koje se odnose na kvalitet, kvantitet, vremensku zasnovanost i kredibilitet izvora imaju uticaj na poverenje potrošača u elektronskoj interpersonalnoj komunikaciji, kao i da se utvrdi da li poverenje korisnika wellness sadržaja doprinosi kupovnom ponašanju.

$\mathrm{Na}$ osnovu realizovanog empirijskog istraživanja, uočeno je da kvantitet informacija, vremenska zasnovanost i kredibilitet izvora poruke u elektronskoj interpersonalnoj komunikaciji imaju pozitivan uticaj na poverenje potrošača, što je u skladu sa prethodnim istraživanjima (Xiaorong, Bin, Qinghong, Liuli \& Yu, 2011, Coursaris, Van Osch \& Albini, 2017, Wu, Chen \& Chung, 2010), dok kvalitet informacija nema statistički značajan uticaj. Prema zaključcima do kojih su došli drugi istraživači, poverenje korisnika značajno determiniše kupovnu nameru (Prasad, Gupta \& Totala, 2017). Kreatori turističke ponude, posebno wellness sadržaja, trebalo bi da kreiraju mogućnost razmene informacija među korisnicima, jer je veći stepen poverenja $\mathrm{u}$ odnosu na podatke koje plasira samo preduzeće. Društvena opravdanost istraživanja odnosi se na mogućnost kako preduzeća, tako i potrošača u oblasti korišćenja wellness sadržaja da utiču na poverenje drugih korisnika u procesu komunikacije.

Empirijskim istraživanjem upućuje se na određene menadžerske implikacije. Ovakva analiza može pomoći razvoju turističkog sektora, preciznije, wellness industriji da se pospeši elektronska interpersonalna komunikacija i analizira ponašanje potrošača u online okruženju. Podsticanjem korisnika da na ovakav način razmenjuju informacije, omogućila bi se veća korist kako za kreatore wellness sadržaja, tako i za potrošače. Većom dostupnošću aktuelnih online komentara, povećava se poverenje potrošača, što često predstavlja ključ uspešog tržišnog pozicioniranja.

Ograničenja sprovedenog empirijskog istraživanja odnose se, pre svega, na činjenicu da je isto realizovano na teritoriji Kragujevca, pa bi u narednim istraživačkim postupcima trebalo proširiti teritoriju na kojoj se vrši ispitivanje. Zatim, u nekom od narednih istraživanja, trebalo bi razgraničiti koji oblici društvenih medija u elektronskom okruženju imaju dominantan uticaj na ponašanje potrošača $u$ elektronskoj interpersonalnoj komunikaciji, kao i da li za različite vidove wellness turizma korisnici iskazuju drugačije preferencije. S obzirom na činjenicu da se $u$ zavisnosti od profila ispitanika razlikuje i spremnost za elektronsku interpersonalnu komunikaciju, trebalo bi ispitati da li između mlađih i starijih ispitanika i njihovog kupovnog ponašanja postoje statistički značajne razlike.

\section{ZAHVALNICA}

Ovaj rad je deo interdisciplinarnog istraživačkog projekta (br. 41010), koji finansira Ministarstvo prosvete, nauke i tehnološkog razvoja Republike Srbije.

\section{REFERENCE}

Abdelaziz, M., Aziz, W., Khalifa, G., \& Ma'youf, M. (2015). Determinants of electronic word of mouth (eWOM) influence on hotel customers' purchase decision. Journal of Faculty of Tourism and Hotels, 9(2/2), 194-221.

Abubakar, A. M. (2016). Does eWOM influence destination trust and travel intention: A medical tourism perspective. Economic Research, 29(1), 598-611. doi:10.1080/133167 7X.2016.1189841

Albarq. A. (2014). Measuring the impacts of online word-ofmouth on tourists' attitude and intentions to visit Jordan: An empirical study. International Business Research, 7(1), 1422. doi:10.5539/ibr.v7n1p14

Alfina, I., Ero, J., Hidayanto, A., \& Shihab, M. (2014). The impact of cognitive trust and eWOM on purchase intention in C2C e-commerce site. Journal of Computer Science, 10(12), 2518-2524. doi:10.3844/jcssp.2014.2518.2524 
Belarmino, A. M., \& Koh, Y. (2018). How eWOM motivations vary by hotel review website. International Journal of Contemporary Hospitality Management, 30(8), 1-22. doi. org/10.1108/IJCHM-02-2017-0055

Bellman, S., Johnson, E., Loshe, G., \& Mandel, N. (2006). Designing marketplaces of the artificial with consumers in mind. Journal of Interactive Marketing, 20(1), 21-33. doi. org/10.1002/dir.20053

Casaló, L. V., Flavián, C., \& Guinaliu, M. (2011). Understanding the intention to follow the advice obtained in an online travel community. Computers in Human Behavior, 27(2), 622633. doi:10.1016/j.chb.2010.04.013

Coulter, K., \& Coulter, R. (2002). Determinants of trust in a service provider: The moderating role of length of relationship. Journal of Services Marketing, 16(1), 35-50. doi:10.1108/08876040210419406

Coursaris, K., Van Osch, W., \& Albini, A. (2017). Antecedents and consequents of trustworthiness in user-generated online reviews: A case of the travel industry. SIGHCI 2017 Proceedings.

Curras-Perez, R., Ruiz, C., Sanchez-Garcia, I., \& Sanz, S. (2017). Determinants of customer retention in virtual environments. The role of perceived risk in a tourism services context. Spanish Journal of Marketing - ESIC, 21(2), 131-145. doi.org/10.1016/j.sjme.2017.07.002

Fan, Y. W., \& Miao, Y. F. (2012). Effect of electronic word-ofmouth on consumer purchase intention: The perspective of gender differences. International Journal of Electronic Business Management, 10(3), 175-181.

Fan, Y. W., Miao, Y. F., Fang, Y. H. \& Lin. R. Y. (2013). Establishing the adoption of electronic word-of-mouth through consumers' perceived credibility. International Business Research, 6(3), 58-65. doi:10.5539/ibr.v6n3p58

Flavián, C., Guinalíu, M., \& Gurrea, R. (2006). The role played by perceived usability, satisfaction and consumer trust on website loyalty. Information \& Management, 43(1), 1-14. doi:10.1016/j.im.2005.01.002

Fu, X., Bin, Z., Qinghong, X., Liuli, X., \& Yu, C. (2011). Impact of quantity and timeliness of eWOM information on consumer's online purchase intention under C2C environment. Asian Journal of Business Research, 1(2), 37-52.
Gommans, M., Krishnan, K., \& Scheffold, K. (2001). From brand loyalty to e-loyalty: A conceptual framework. Journal of Economic and Social Research, 3(1), 43-58.

Hennig-Thurau, T., \& Walsh, G. (2003). Electronic word-ofmouth: Motives for and consequences of reading customer articulations on the internet. International Journal of Electronic Commerce, 8(2), 51-74. doi.org/10.1080/10864415.20 03.11044293

Hennig-Thurau, T., Gwinner, K. P., Walsh, G., \& Gremler D. (2004). Electronic word-of-mouth via consumer-opinion platforms: What motivates consumers to articulate themselves on the internet. Journal of Interactive Marketing, 18(1), 38-52. doi.org/10.1002/dir.10073

Hu, N., Bose, I., Koh, N. S., \& Liu, L. (2012). Manipulation of online reviews: An analysis of ratings, readability, and sentiments. Decision Support Systems, 52(3), 674-684. doi:10.1016/j.dss.2011.11.002

Kimery, K. M., \& McCord, M. (2002) .) Third-party assurances: Mapping the road to trust in e-retailing. Journal of Information Technology Theory and Application, 4(2), 64-82.

Koncul, N. (2012). Wellness: A new mode of tourism. Economic Research, 25(2), 525-534. doi.org/10.1080/133167 7X.2012.11517521

Kursan, Milaković, I., Mihić, M., \& Ivasečko, N. (2017). Antecedents of traditional and electronic word of mouth communication: Student population based study. Mostariensia, 21(1), 97-111.

Lin, C., Wu, Y., \& Chen, J. (2013). Electronic word-of-mouth: The moderating roles of product involvement and brand image. Paper presented an the International conference on technology innovation and Industrial Management, Phuket, Thailand.

Lopez, M., \& Sicilia, M. (2014). Determinants of eWOM influence: The role of consumers' internet experience. Journal of Theoretical and Applied Electronic Commerce Research, 9(1), 28-43. doi:10.4067/s0718-18762014000100004

Marić, D., Kovač Žnideršić, R., Paskaš, N., Jevtić, J. i Kanjuga, Z. (2017). Savremeni potrošač i elektronska interpersonalna komunikacija. Marketing, 48(3), 147-154. doi:10.5937/ Markt1703147M 
Marinković, V., Senić, V., Obradović, S., \& Šapić, S. (2012). Understanding antecedents of customer satisfaction and word-of-mouth communication: Evidence from hypermarket chains. African Journal of Business Management, 6(29), 8515-8524. doi:10.5897/AJBM11.1455

Mueller, H., \& Kaufmann, E. (2001). Wellness tourism: Market analysis of a special health tourism segment and implications for the hotel industry. Journal of Vacation Marketing, 7(1), 7-15. doi.org/10.1177/135676670100700101

Nunnally, J. C. (1978). Introduction to Psychological Measurement. New York, NY: McGraw-Hill.

Prasad, S., Gupta, I., \& Totala, N. (2017). Social media usage, electronic word of mouth and purchase-decision involvement. Asia-Pacific Journal of Business Administration, 9(2), 134-145. doi.org/10.1108/APJBA-06-2016-0063

Republički zavod za statistiku. (2018). Upotreba informacionokomunikacionih tehnologija u Republici Srbiji. Preuzeto 11. januara 2019 sa http://publikacije.stat.gov.rs/G2018/Pdf/ G201816013.pdf

Sa'ait, N., Kanyan, A., \& Fitri Nazrin, M. (2016). The effect of ewom on customer purchase intention. International Academic Research Journal of Social Science, 2(1), 73-80.

Sapic, S. (2017). The effects of Cosmopolitanism and Tradition on the Evaluation and Intentions of the Users of Fast Food Restaurants. Economic Horizons, 19(2), 83-95. doi:10.5937/ ekonhor1702081S

Senić, R. i Senić, V. (2008). Menadžment i marketing usluga. Kragujevac, Republika Srbija: Prizma.
Shuqair, S., Cragg, P., Zaidan, A., \& Mitchell, T. (2016). The influence of users generated content on attitude towards brand and purchase intentions - Case of Bahrain. International Journal of Business Marketing and Management, $1(5), 9-20$.

Stanković, Lj. i Đukić, S. (2014). Marketing komuniciranje. Niš, Republika Srbija: Ekonomski fakultet Univerziteta u Nišu.

Težak Damijanić, A., \& Šergo, Z. (2014). Determining travel motivations of wellness tourism. Ekonomska misao i praksa, 1, 3-20.

Trusov, M., Bucklin, R. E., \& Pauwels, K. (2009). Effects of word-of-mouth versus traditional marketing: Findings from an internet social networking site. Journal of Marketing, 73(5), 90-102. doi.org/10.1509/jmkg.73.5.90

Wu, J., Chen, Y., \& Chung, Y. (2010). Trust factors influencing virtual community members: A study of transaction communities. Journal of Business Research, 63(9-10), 10251032.

Xiaorong, F., Bin, Z., Qinghong, X., Liuli, X., \& Yu, C. (2011). Impact of quantity and timeliness of eWOM information on consumer's online purchase intention under $\mathrm{C} 2 \mathrm{C}$ environment. Asian Journal of Business Research, 1(2), 3-52.

Zainal, N. T. A., Harun, A., \& Lily, J. (2017). Examining the mediating effect of attitude towards electronic words-of mouth (eWOM) on the relation between the trust in eWOM source and intention to follow eWOM among Malaysian travelers. Asia Pacific Management Review, 22(1), 35-44. doi:10.1016/j.apmrv.2016.10.004

Primljeno 31. januara 2019, nakon revizije, prihvaćeno za publikovanje 17. aprila 2019. Elektronska verzija objavljena 25. aprila 2019. 
Milan Kocić je vanredni profesor Ekonomskog fakulteta Univerziteta u Kragujevcu, gde je i doktorirao iz oblasti Marketinga. Angažovan je na nastavnim predmetima Marketing, Tržišno komuniciranje i Direktni marketing na osnovnim studijama, i na predmetima Marketing menadžment i Strategijski marketing na master, odnosno, doktorskim studijama. Glavne oblasti njegovog interesovanja su marketing, brendiranje i marketinške komunikacije.

Katarina Radaković je asistent na Ekonomskom fakultetu Univerziteta u Kragujevcu. Master studije završila je na istom fakultetu, gde je trenutno student doktorskih studija. Izvodi vežbe na nastavnim predmetima Marketing, Tržišno komuniciranje i Direktni marketing. Najznačajnije oblasti istraživanja su marketing i ponašanje potrošača.

\title{
THE IMPLICATIONS OF THE ELECTRONIC WORD-OF- MOUTH COMMUNICATION IN CHOOSING A WELLNESS OFFER
}

\author{
Milan Kocic and Katarina Radakovic \\ Faculty of Economics, University of Kragujevac, Kragujevac, The Republic of Serbia
}

In the conditions of the dynamic development of information and communications technology, the traditional way of establishing communication among consumers has significantly changed. As one of several extremely important marketing instruments, word-of-mouth communication has been assuming a new dimension via digital forms of communicating. Having in mind the significance of social media for the formation of consumer attitudes and intentions concerning the purchasing process, the paper is aimed at obtaining relevant findings on the effect of electronic word-of-mouth communication on consumer behavior. More precisely, by using a correlation and multiple regression analysis, whether the quantity, quality and timeliness of information, and the source credibility of electronic word-of-mouth communication affect consumer trust in the area of a wellness offer was examined. A simple regression analysis was applied in order to determine whether consumer trust contributed to purchase intention. The results of the conducted empirical research show that there is a statistically significant impact of electronic word-of-mouth communication on consumer trust and that consumer trust positively affects purchase intention when choosing a wellness package in the Republic of Serbia is concerned.

Keywords: electronic word-of-mouth communication, consumer attitudes, purchasing behavior, social media, wellness offer

JEL Classification: M31, D830, I0 